\title{
THE LIVER IN HEART FAILURE RELATION OF ANATOMICAL, FUNCTIONAL, AND CIRCULATORY CHANGES
}

\author{
BY \\ SHEILA SHERLOCK \\ From the Department of Medicine, Postgraduate Medical School of. London \\ Received May 3, 1950
}

A congested " nutmeg" liver is a common post-mortem finding in patients dying from heart failure and the microscopic description dates from Kiernan (1833). Similarly, it is known that biochemical tests of liver function are abnormal in circulatory failure (Jolliffe, 1930; Bernstein, Le Winn and Simkins, 1942; Chávez, Sepúlveda and Ortega, 1943). However, the correlation of functional changes with the hepatic histology has not been attempted in a series of any magnitude, and the evolution of liver changes from mild to severe heart failure requires elucidation. Aspiration liver biopsy and various biochemical tests have been utilized in this attempt to clarify some of the outstanding problems. In many instances hæmodynamic data were available from cardiac catheter studies.

\section{METHODS}

Liver tissue was obtained by a modification (Sherlock, 1945) of the aspiration liver biopsy technique of Iversen and Roholm (1939). Hæmorrhage might be anticipated from puncture of the " congested" liver of heart failure, but the 41 biopsies performed were uncomplicated and well tolerated. Necropsy material is of limited value owing to rapid autolysis, as will be described later. It was never used to evaluate cellular changes, but liver puncture material taken within two hours of death was occasionally used to assess fibrosis.

Material fixed in 10 per cent formol-saline was stained with hæmatoxylin and eosin, with a modified silver impregnation method for reticulin and with Mallory's picric stain for connective tissue. The presence of fat was checked by Sudan III frozen sections. Faint staining with methylene blue showed up bile pigment. Iron was demonstrated by the Prussian blue method, and glycogen by Best's carmine stain on alcohol fixed tissue.

A full post-mortem examination was carried out in 28 patients, particular attention being paid to the colour of the bile and the state of the bile passages, ascites, infarction in the organs, the size of the spleen, and the possibility of a portal collateral circulation.

Biochemical methods. Serum was analysed for bilirubin by the method of Haslewood and King (1937), for alkaline phosphatase by the method of King and Armstrong (1934), and for proteins, King et al. (1937, 1942). The technique of Maclagan (1944) was used for the colloidal gold reaction. The bromsulphalein test using $5 \mathrm{mg}$. $/ \mathrm{kg}$. body weight was employed according to Helm and Machella (1942). Urine urobilinogen was determined qualitatively by Erhlich's reagent, and quantitatively on 24-hour samples by the method of Watson (1937). Schlesinger's test was used for urobilin. - The methylene blue method of Gellis and Stokes (1945) and diazo tests of Pollock (1945) were employed for urine bilirubin determinations. Normal values for these methods are shown in Tables II and IV.

Circulatory studies. Cardiac output (CO) and right auricular pressure (RAP) were estimated by the technique described by McMichael and Sharpey-Schafer (1944). Arterial oxygen saturation was sometimes measured. 
As all these investigations could not be performed on the same day, the cardiac catheterization and the biochemical studies were done together and the liver biopsy within three days of these.

\section{Clinical material}

It was inevitable that some selection of patients should occur, the association of visible icterus and heart failure prompting investigation. To balance this, patients in heart failure, not obviously jaundiced, were also included. Fifty-one patients.were studied with all the common ætiological varieties of acquired heart disease. Apart from one patient with constrictive pericarditis the fifty other patients were all in congestive heart failure as judged by increased jugular venous pressure, presence of crepitations at the lung bases, tenderness of the liver, and peripheral œdema.

The extent of centrilobular hepatic necrosis was graded as follows.

(A) The hepatocellular changes confined to the region immediately adjoining the centrilobular hepatic vein (18 patients).

(B) Liver cell necrosis extended from the central vein one-third the distance towards the periphery of the lobule (15 patients).

(C) Disappearance of liver cells over an area greater than the inner third of the lobules (17 patients).

The two more severe grades are illustrated in Fig. 1 and 2. To avoid bias the grading was done by one observer without clinical or other data.

\section{General Description of the Liver in Heart Failure}

Liver weights were variable and bore no relation to the clinical assessment of hepatic size. This might be due to drainage of blood post mortem from an over-distended liver. The disparity between the finding at necropsy of a liver of normal weight, and the clinical signs during life of hepatic enlargement, was perhaps explicable on this basis.

Hepatic histology. The general anatomy of the lobule was usually intact, the portal tracts bearing their normal relationship to the central hepatic vein (Fig. 2). Sometimes the lobular. pattern was reversed, the portal tracts apparently lying centrally with a ring of surrounding fibrous tissue passing from central vein to central vein. This was characteristic of cardiac cirrhosis.

The central vein was always dilated and the sinusoids entering it were engorged for a variable distance towards the periphery of the lobule. In severe cases there was frank hæmorrhage from the sinusoids (Fig. 1 and 10). There was usually some disappearance of liver cells. The remaining liver cells showed a variety of degenerative changes. The cytoplasm was shrunken with excessive granularity. The nuclei showed fragmentation and pyknosis, these changes diminishing in intensity as the portal zones were reached (Fig. 2). Apart from cardiac cirrhosis the portal tracts were essentially normal (Fig. 2 and 5). Each portal tract was surrounded by relatively normal liver cells to a depth that varied inversely with the central necrosis.

Diffuse loss of liver glycogen was noted only in the agonal stages. Surviving cells usually contained their normal complement of glycogen. This was true not only of the relatively normal portal zone but also of the surviving liver cells lying amidst the debris at the centre of the lobule. Biopsy sections showed significant fatty change in only 15 of the 41 available sections. The fat was in scattered droplets (Fig. 10); only rarely was there distension of the liver cell by one large globule. Sometimes the fatty change was peripheral (8 cases), occasionally central (3 cases) or diffusely scattered through the lobule (4 cases). This contrasted completely with the usual post-mortem picture.

Increased brown pigment in the liver cells at the centre of the lobule was constant. In many instances large pigment granules filled the central degenerating cells. As the cells disintegrated the pigment came to lie free at the centre of the lobule amidst cellular debris. This brown pigment failed to give the Prussian blue reaction and was also negative to tests for hæmofuscin. Sudan III stained the granules a rich brown, both in frozen and formol fixed sections. The pigment stained green with methylene blue suggesting a relationship to bile pigment. 


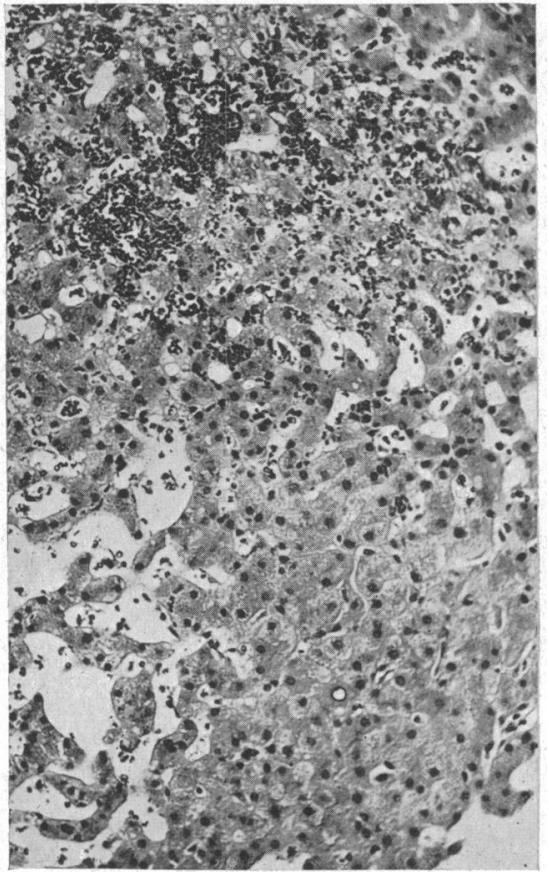
FIG. 1.-Grade B. Ischæmic heart failure.
Serum bilirubin, $2 \cdot 1 \mathrm{mg} . / 100 \mathrm{ml}$.; RAP, $+27 \mathrm{~cm}$. saline; $\mathrm{CO}, 4.5 \mathrm{l}$./minute. Liver cells have disappeared from the centre of the lobule and are replaced by frank hæmorrhage. Liver cells peripherally show some degenerative changes and "glycogenic" infiltration in their nuclei is conspicuous. $H$. and $($ E. $\times 120)$.

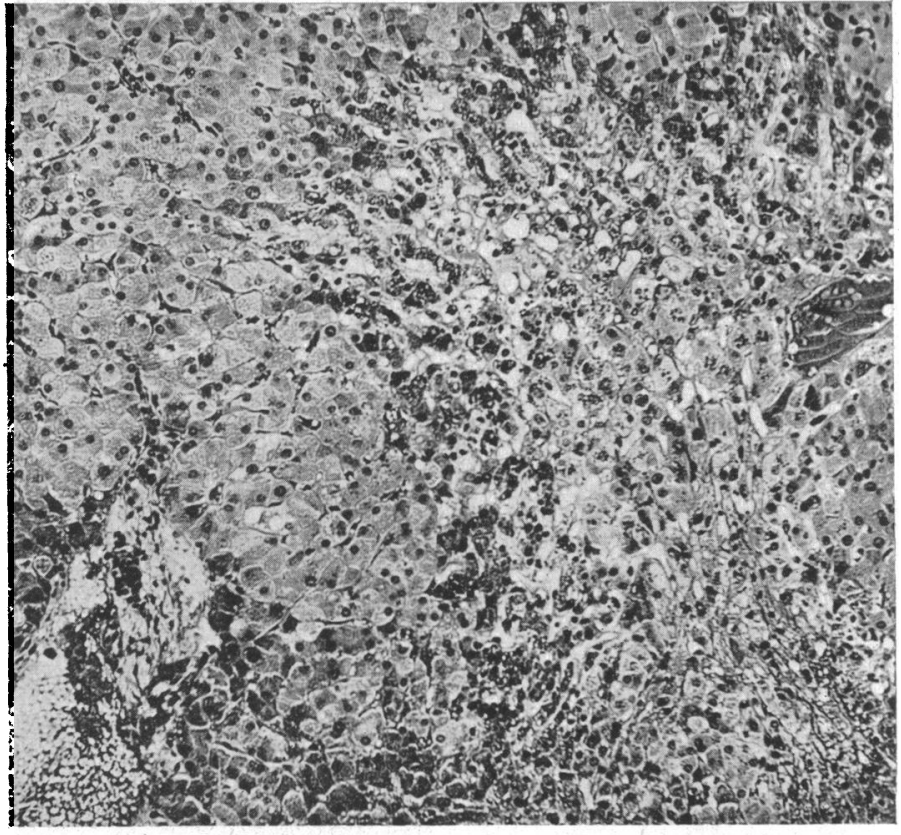

FIG. 2.-Grade C. Case 5. Cor pulmonale; two hours before death. Serum bilirubin, $3.4 \mathrm{mg} . / 100 \mathrm{ml}$.; $\mathrm{RAP},+16 \mathrm{~cm}$. saline; $\mathrm{CO}$, 3.5 1./minute and arterial oxygen saturation 59 per cent. Gross centrilobular congestion and liver cell necrosis. Pigment increase is seen in the degenerating liver cells. Liver cells at the periphery of the lobule are relatively normal. H.E. $(\times 120)$.

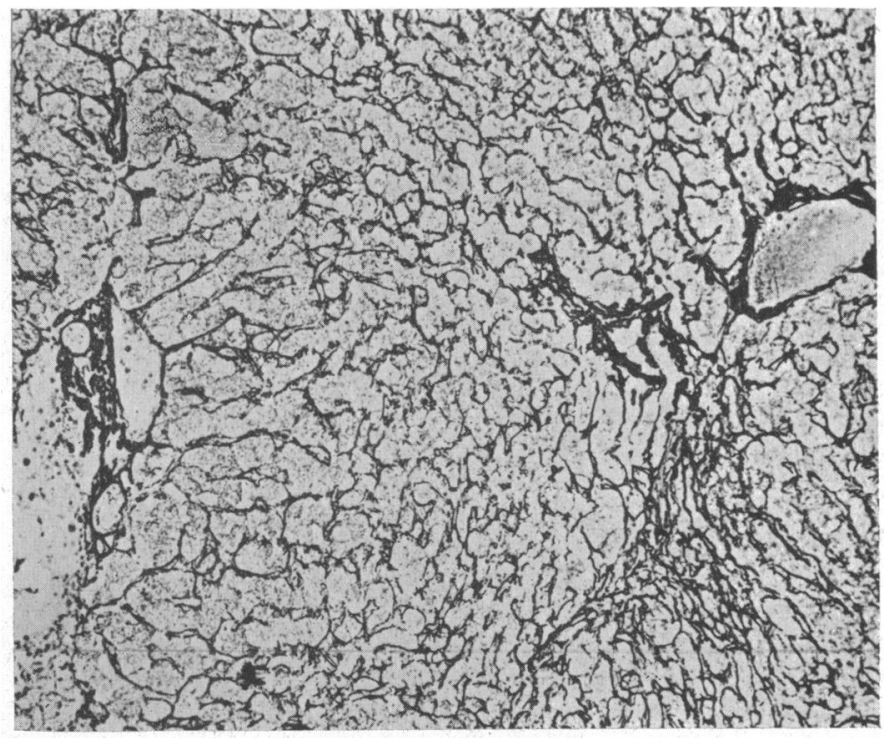

FIG. 3.-Case 5. Reticulin stains show condensation at the lobular centre. $(\times 120)$. 


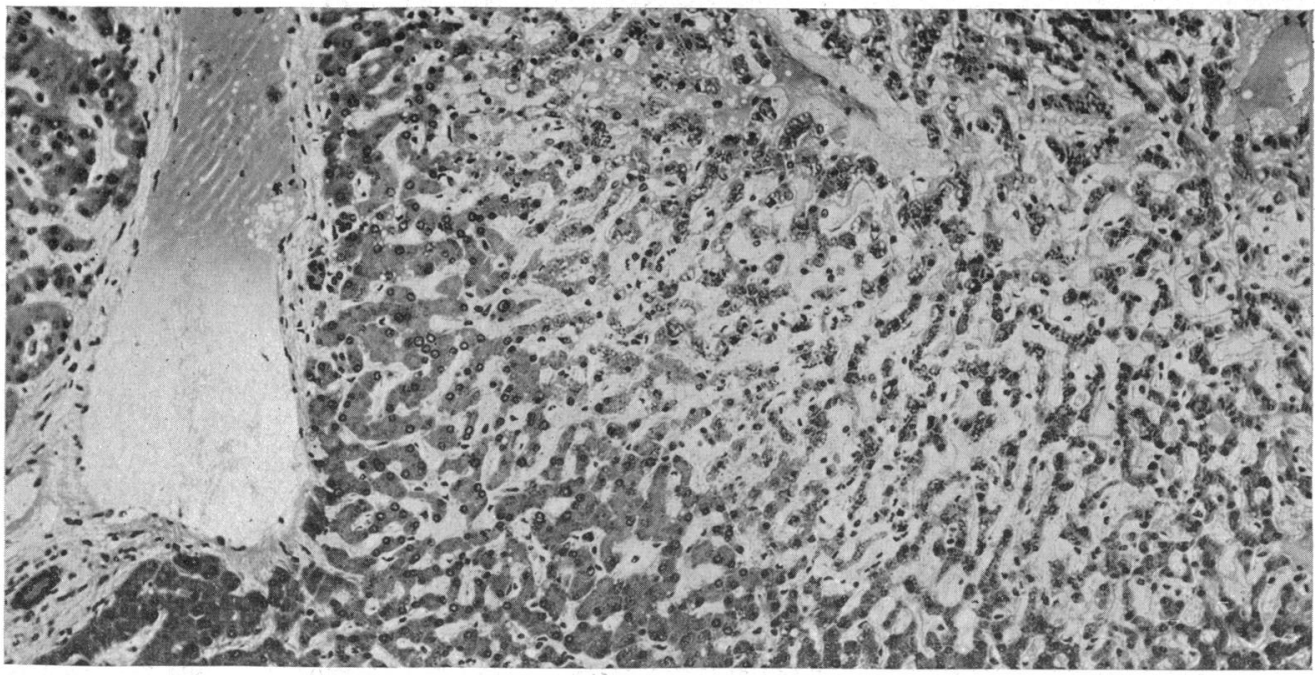

Fig. 4.-Case 5. Twelve hours post mortem. The necrosis has appárently extended. Liver cells are smaller and darker and the perisinusoidal spaces are open. H.E. $(\times 120)$.

Methylene blue sometimes showed excess of bile pigment in the minute bile channels (" bile thrombi "), especially in the periportal region. Large numbers were seen in ten patients, in general, the most deeply jaundiced. The mean serum bilirubin for this group was $3.7 \mathrm{mg} . / 100 \mathrm{ml}$. compared with $2.1 \mathrm{mg}$. $/ 100 \mathrm{ml}$. for the whole series. Iron was not increased either in liver cells or in Küpffer cells. There was no relationship between the increased central brown pigment or bile pigment and hæmosiderosis.

\section{The Course of Centrilobular Hepatic Cell Necrosis in Heart Failure}

If the heart does not respond to therapy the necrosis spreads towards the periphery of the hepatic lobule. This is illustrated by the following case history.

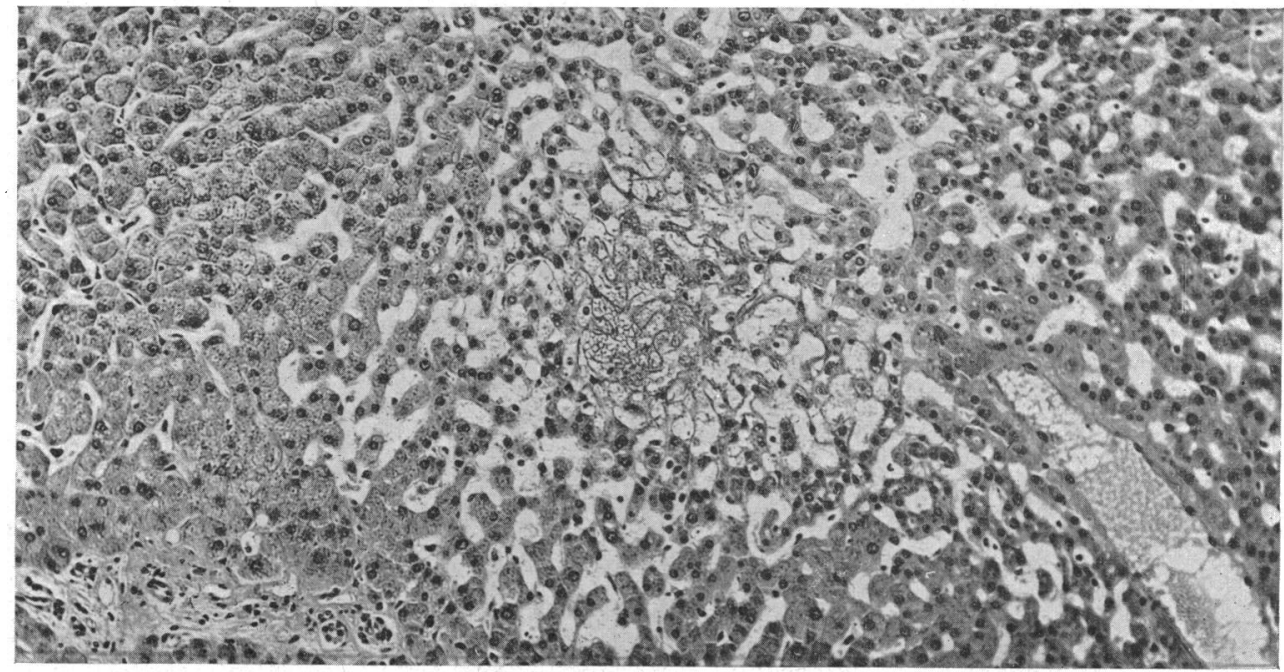

FIG 5.-Case 1. Hypertensive heart failure: 4/4/45. Serum bilirubin, $1.3 \mathrm{mg} . / 100 \mathrm{ml}$. Grade B lesion. H.E. $(\times 120)$. 
Case 1, H. S., man, aged 55, admitted 1/4/45. Hypertensive heart failure for two months. 4/4/45; serum bilirubin, $1.3 \mathrm{mg}$./100 ml.; bromsulphalein retention, 36 per cent. Hepatic biopsy showed congestive disorganization of the lobular centres (grade B). In places there was frank hæmorrhage into the central areas. Sinusoids distended and liver cell columns narrowed. No

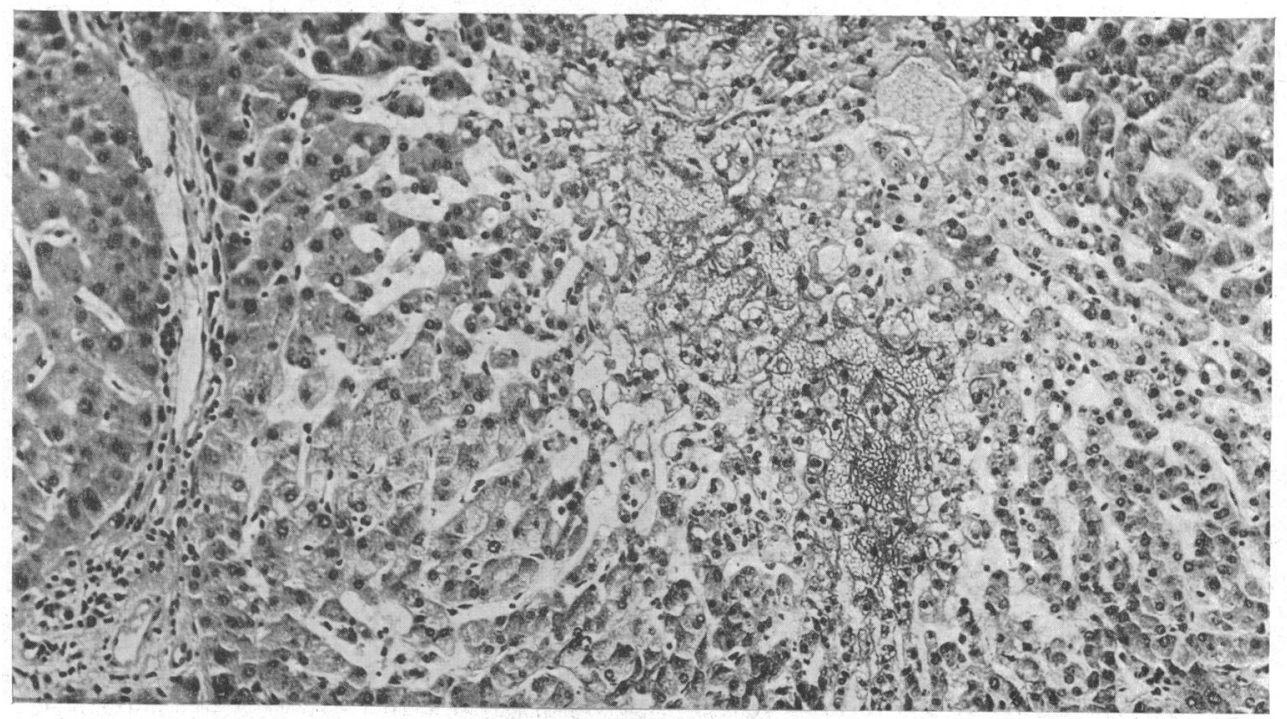

Fig. 6. -Case 1. 17/4/45. Serum bilirubin, $1.0 \mathrm{mg} . / 100 \mathrm{ml}$. Grade $\mathrm{C}$ lesion. H.E. $(\times 130)$.

fatty change. Portal tracts normal (Fig. 5). Apart from some central condensation of fibres, reticulin pattern normal. 17/4/45-CO, $2 \cdot 6$ 1./minute. RAP, $24 \mathrm{~cm}$. saline. Serum bilirubin level, $1.0 \mathrm{mg} . / 100 \mathrm{ml}$. Second hepatic biopsyextension of the necrosis (Fig. 6). Inner twothirds of the lobule completely disorganized. Hæmorrhage persistent. Patient died 23/4/45.

This case record illustrates the rapidity with which liver cell necrosis can increase in the presence of uncontrolled congestive heart failure. Jaundice does not necessarily deepen.

If the cardiac failure responds to treatment the centrilobular necrosis may heal, and even if there is a definite cardiac cirrhosis, hepatic function may be adequate. This is illustrated by the following case history.

Case 2, E. M., man, aged 59, long standing winter bronchitis and pulmonary emphysema. January, 1946, admitted in pulmonary cardiac failure. $8 / 1 / 46$; serum bilirubin, $1.3 \mathrm{mg}$.; serum albumin, $2 \cdot 2 \mathrm{~g}$.; serum globulin, $4 \cdot 2 \mathrm{~g}$. (all per $100 \mathrm{ml}$.) 43 per cent retention of bromsulphalein. Urine bilirubin present and urobilinogen excessive. RAP $+8 \mathrm{~cm}$. saline, $\mathrm{CO}, 5.71$./minute

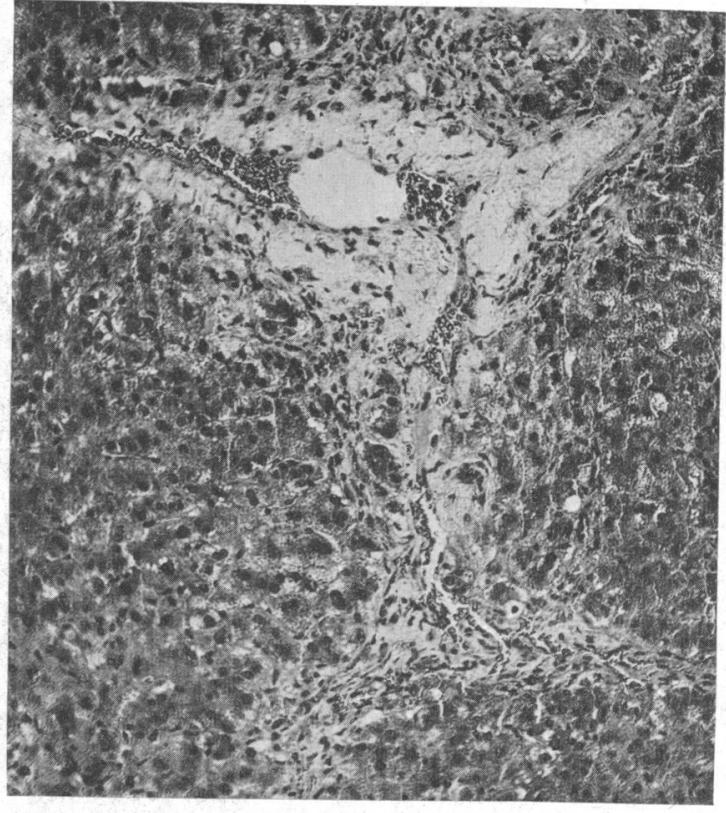

Frg. 7.-Case 2 . Cor pulmonale: $8 / 1 / 46$. Serum bilirubin, $1 \cdot 3 / 100 \mathrm{ml}$.; 43 per cent retention of bromsulphalein at 30 minutes. Lobular centres show fibrous tissue with some hæmorrhage. Adjoining liver cells show degenerative changes. H.E. $(\times 120)$. 
(high output type); arterial oxygen saturation, 48 per cent. Hepatic biopsy, I. Conspicuous centrilobular congestion with necrosis. Liver cells contain excess golden brown pigment. Centrilobular condensation of reticulin with formation of new connective tissue. Lesion is an early cardiac cirrhosis (Fig. 7). Patient made an unexpectedly good recovery and six months later was no longer in cardiac failure. $13 / 7 / 46$; serum bilirubin less than $0.5 \mathrm{mg}$.; serum albumin, $4 \cdot 1$; and serum globulin, $3.3 \mathrm{~g}$., all per $100 \mathrm{ml}$. Ten per cent retention of bromsulphalein. Urine: no bilirubin or urobilinogen. Hepatic biopsy, II. The acute change has subsided. Necrotic areas replaced by dense collagenous connective tissue in which a few pigmented liver cells remain trapped. Reticulin stains show only black fibres. No new reticulin formation. Early cardiac cirrhosis confirmed (Fig. 8 and 9).

With control of the heart failure there was healing of the liver cell damage. An inactive cardiac cirrhosis remained. This could not have been readily detected by clinical or biochemical means but was demonstrated by hepatic biopsy.

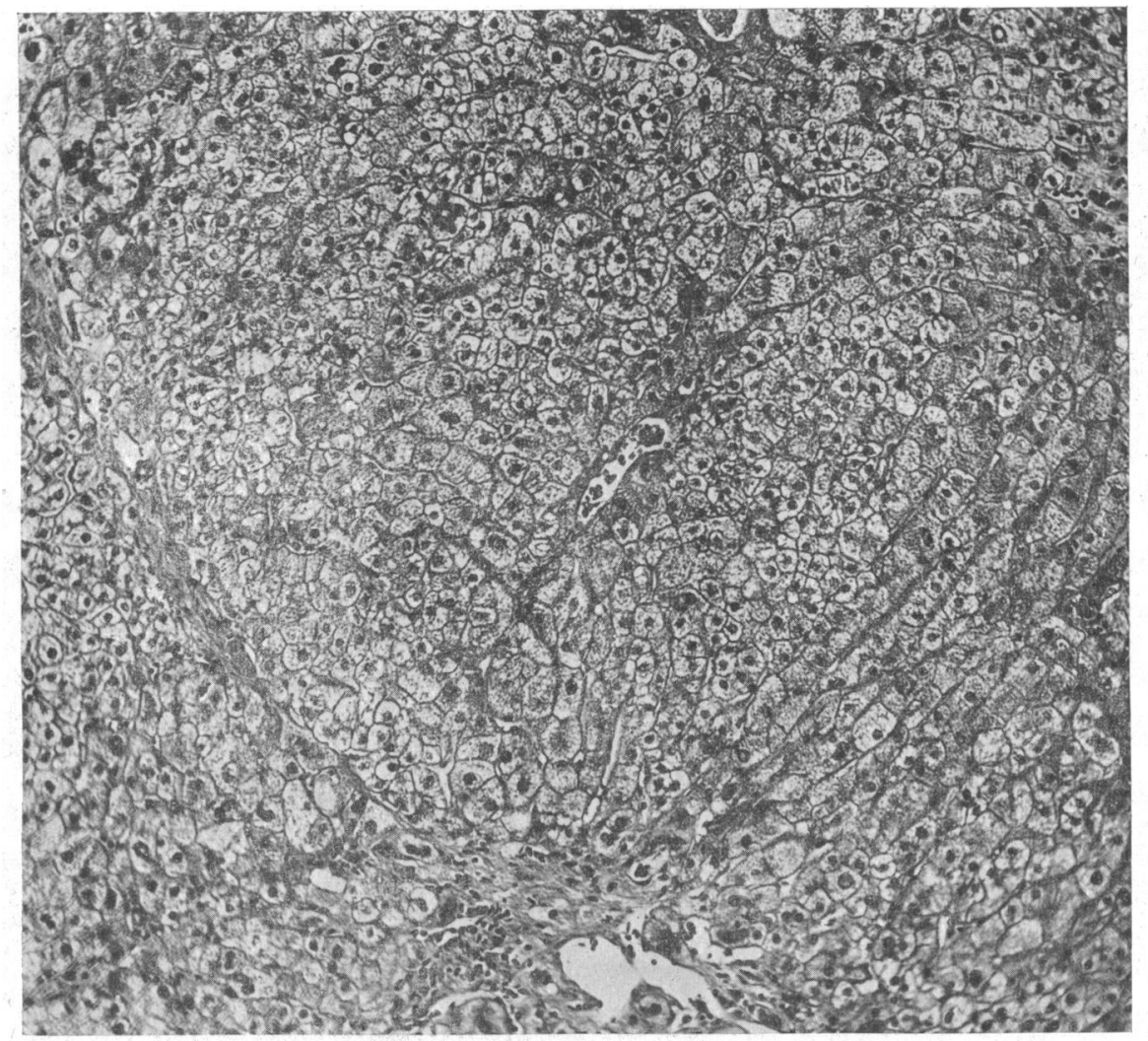

Fig. 8. Case 2. 13/7/46. Serum bilirubin, $0.5 \mathrm{mg} . / 100 \mathrm{ml}$.; 10 per cent retention of bromsulphalein at $30 \mathrm{minutes}$. Inactive cardiac cirrhosis. Liver cells contain their normal complement of glycogen. A portal tract occupies a central position and normal bands of fibrous tissue pass from central area to central area. H.E. $(\times 120)$.

\section{Fibrous Tissue Changes and Cardiac Cirrhosis}

In the mildest cases (Grade A) the reticulin pattern is normal. The occasional association of much liver cell damage with an intact reticulin framework is usually seen in acute heart failure of short duration. The next stage is centrilobular reticulin condensation (Fig. 3). Liver cells have been lost from the centres of the lobule and this has resulted in collapse of the reticulin stromaa very common finding in heart failure. 


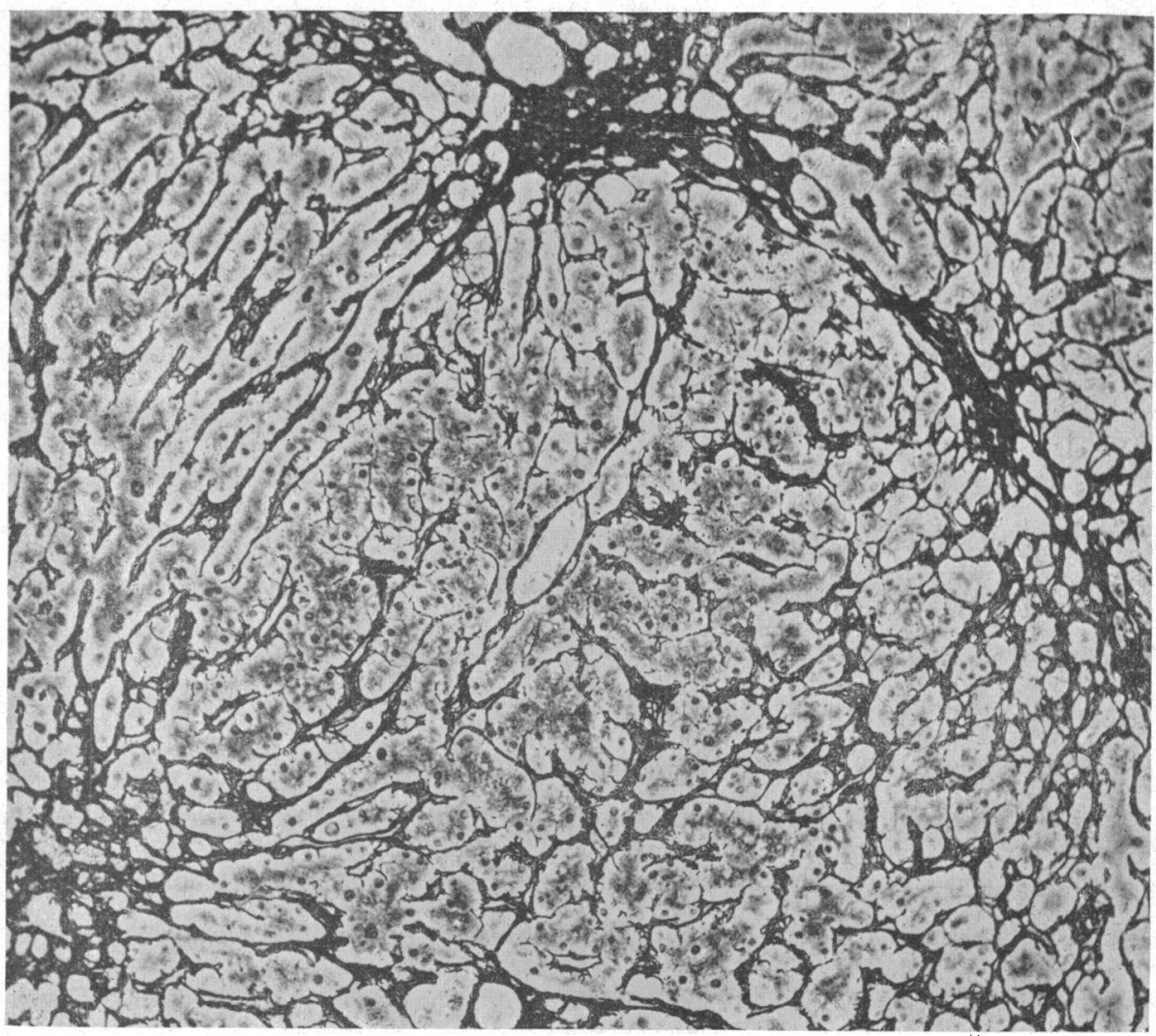

FIG. 9.-Same field as shown in Fig. 11. Reticulin stains confirm the cardiac cirrhosis. $(\times 120)$.

Then follows centrilobular reticulin proliferation. Not only are the reticulin fibres more closely packed together but there is actual production of new reticulin at the centre of the lubule. This is seen as golden yellow fibres in the silver impregnated sections (Fig. 12). A centrilobbular increase in collagen is also found. The central vein is itself thickened and shows a reduplication of reticulin fibres in its wall (phlebosclerosis). The connective tissue extends outwards for a variable distance but does not reach the periphery of the lobule.

If the heart failure continues or relapses, the connective tissue from one central vein joins connective tissue from the central areas of adjoining lobules. The portal areas become surrounded by a ring of fibrous tissue passing from central vein to central vein. This gives the appearance of reversed lobulation. This lesion is a frank cardiac cirrhosis (Fig. 9 and 13). The portal tracts may remain unaffected, but in long standing cases they are often also involved; the bile ducts proliferate, fibroblasts are seen, and sometimes there is also a little round-celled proliferation. When there are changes in both central areas and portal tracts a complex " mixed " picture results (Fig. 15). This may be difficult to distinguish from the usual type of portal cirrhosis. Careful study, however, usually demonstrates that the maximal fibrosis is centrilobular. In some instances nodular regeneration of liver cells may be seen.

Progression of fibrosis in the presence of continuous heart failure is illustrated by the following case history.

Case 3, M. H., woman, aged 26; rheumatic mitral and aortic valvular disease. 21/7/44, admitted in congestive cardiac failure for first time. 26/8/44, patient slightly jaundiced. Serum bilirubin, $2.7 \mathrm{mg}$./100 ml., 53 per cent retention of bromsulphalein; serum alkaline phosphatase, 8.8 units; 
serum albumin, $2 \cdot 4 \mathrm{~g}$., serum globulin, $2 \cdot 8 \mathrm{~g}$. (all per $100 \mathrm{ml}$.). Urıne: bilirubin and urobilin present. Hepatic biopsy, I. Intense congestion of the lobular centres, disappearance of liver cells (grade C). Sinusoids dilated with peripheral fatty change (Fig. 10). Condensation of reticulin at the lobular centre; formation of much new connective tissue. Patient progressively more

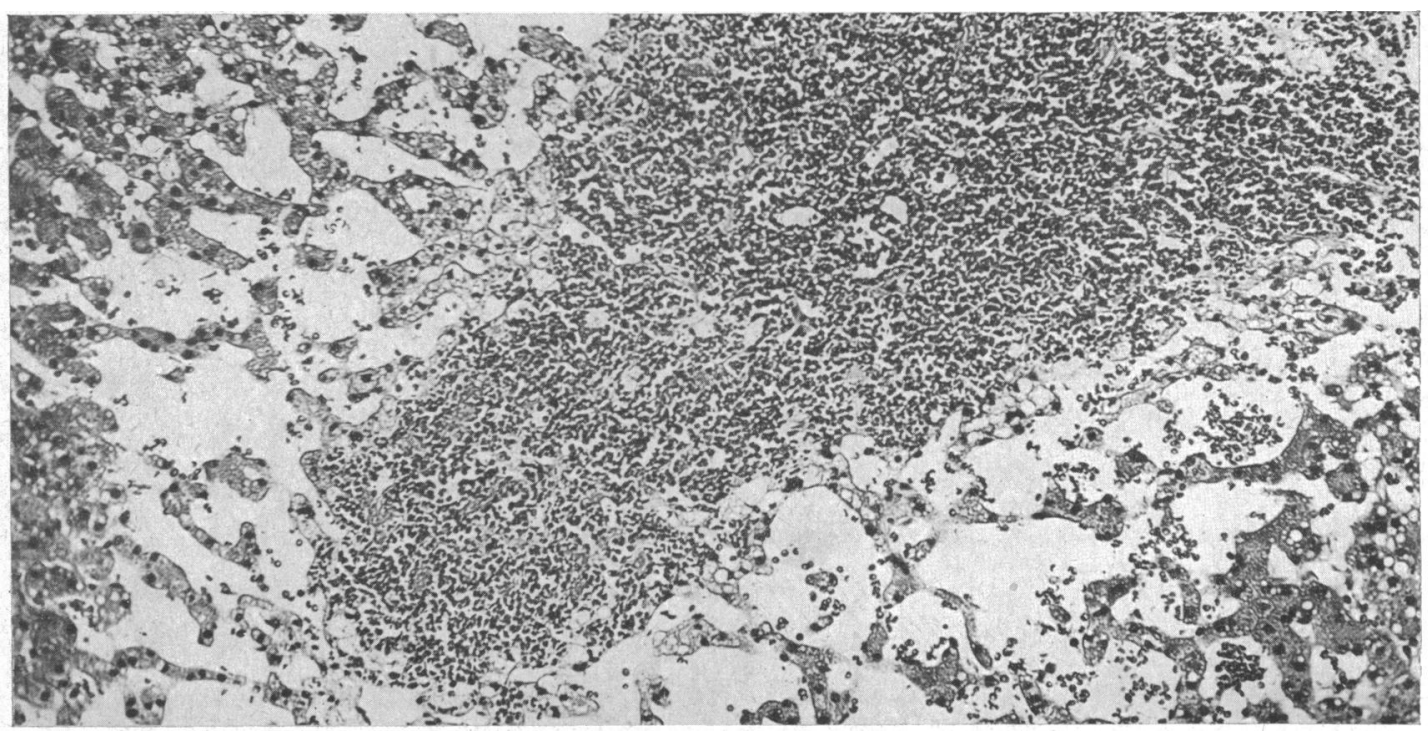

Fig. 10.-Case 3. Mitral and aortic valvular disease: $26 / 8 / 44$. Serum bilirubin, $2 \cdot 7 \mathrm{mg} . / 100 \mathrm{ml}$. Grade C lesion. Extreme centrilobular congestion and necrosis of liver cells with fatty change at the periphery of the lobule. H.E. (x 135).

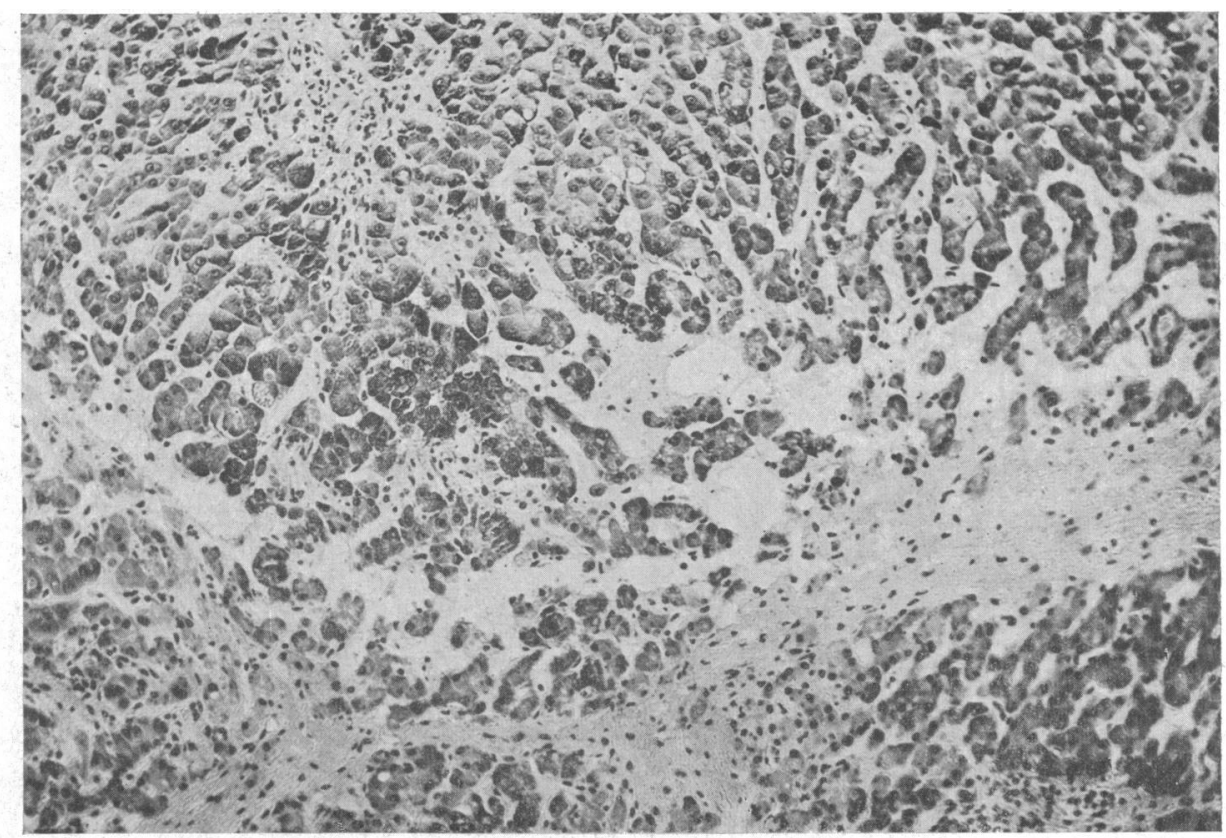

FIG. 11. - Case 3. 16/9/44. Serum bilirubin, $22.0 \mathrm{mg} . / 100 \mathrm{ml}$. RAP, $+29 \mathrm{~cm}$. saline; CO, 2.81./minute. Extension of the lesion with linkage of centrilobular areas by bands of fibrous tissue. Surviving liver cells retain their glycogen. Best's carmine. $(\times 120)$. 


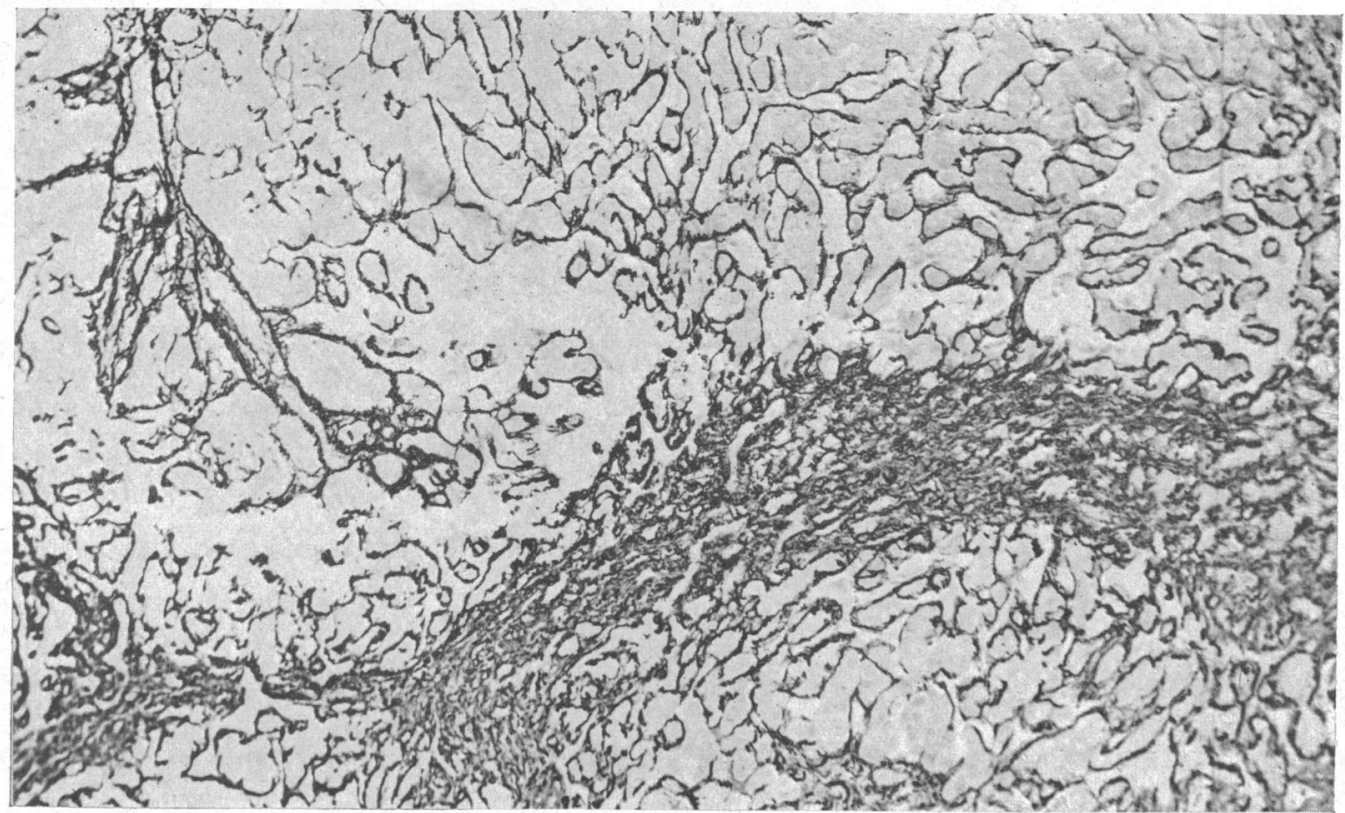

FIG. 12.-Case 3. Reticulin stains show proliferation with bands passing from central area to central area. Modified Foot. $(\times 120)$.

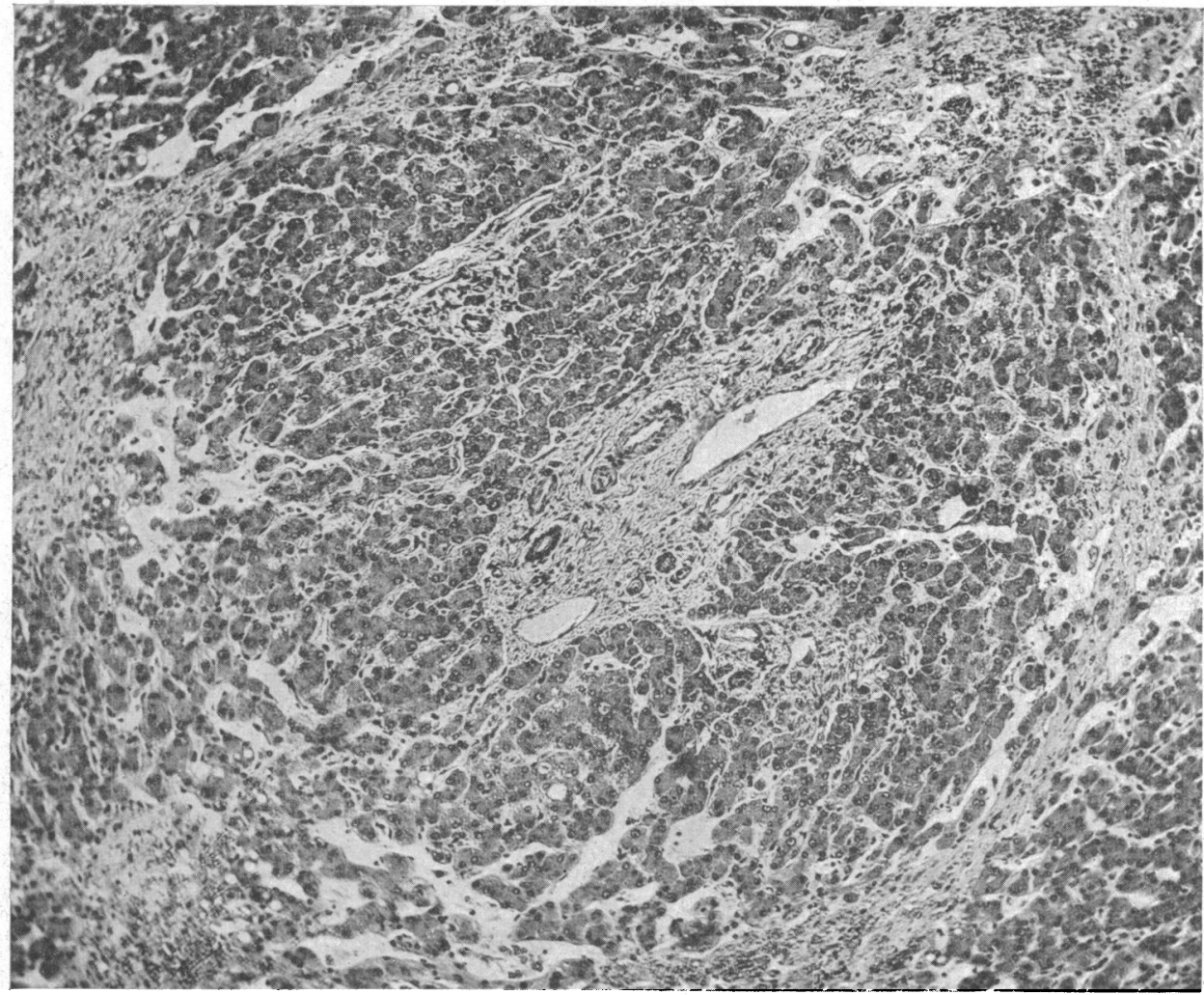

Fig. 13.-Case 3. 26/9/44. Serum bilirubin, $25 \mathrm{mg}$. $/ 100 \mathrm{ml}$. Post-mortem sections show fibrous tissue bands passing from central vein to central vein. There is " reversed lobulation " and a fully developed cardiac cirrhosis. Portal tracts show only slight fibrosis. H.E. $(\times 90)$. 


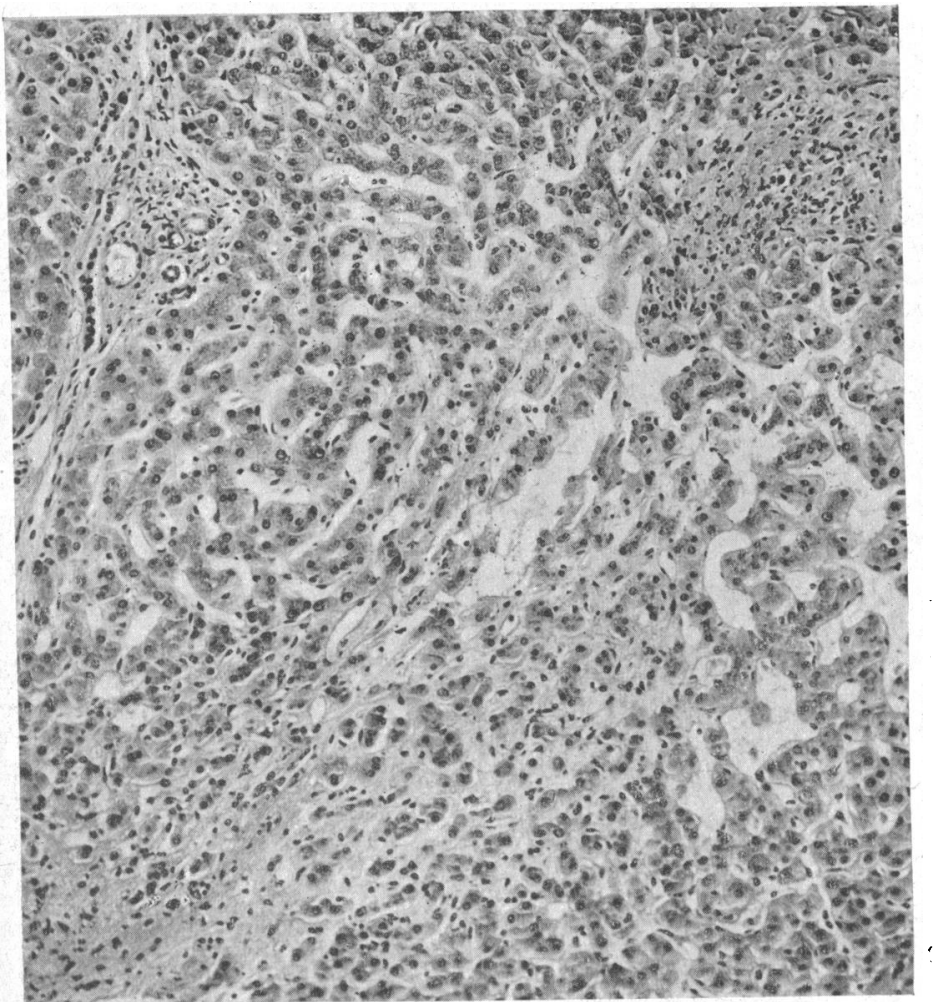

Fig. 14-Case 4. Mitral stenos is : $15 / 2 / 45$. Serum bilirubin, $0.5 \mathrm{mg} . / 100$ ml.; 10 per cent bromsulphalein at 30 minutes. Fully developed inactive cardiac cirrhosis. Portal tracts are relatively unaffected.

Fig. 15.-Case 4. 25/2/46. Serum bilirubin, 1.6 $\mathrm{mg} . / 100 \mathrm{ml}$.; 31 per cent retention of bromsulphalein at 30 minutes. Post-mortem sections show an active cardiac cirrhosis. Portal tracts are also involved giving a mixed portal and cardiac cirrhosis. H.E. $(\times 120)$.

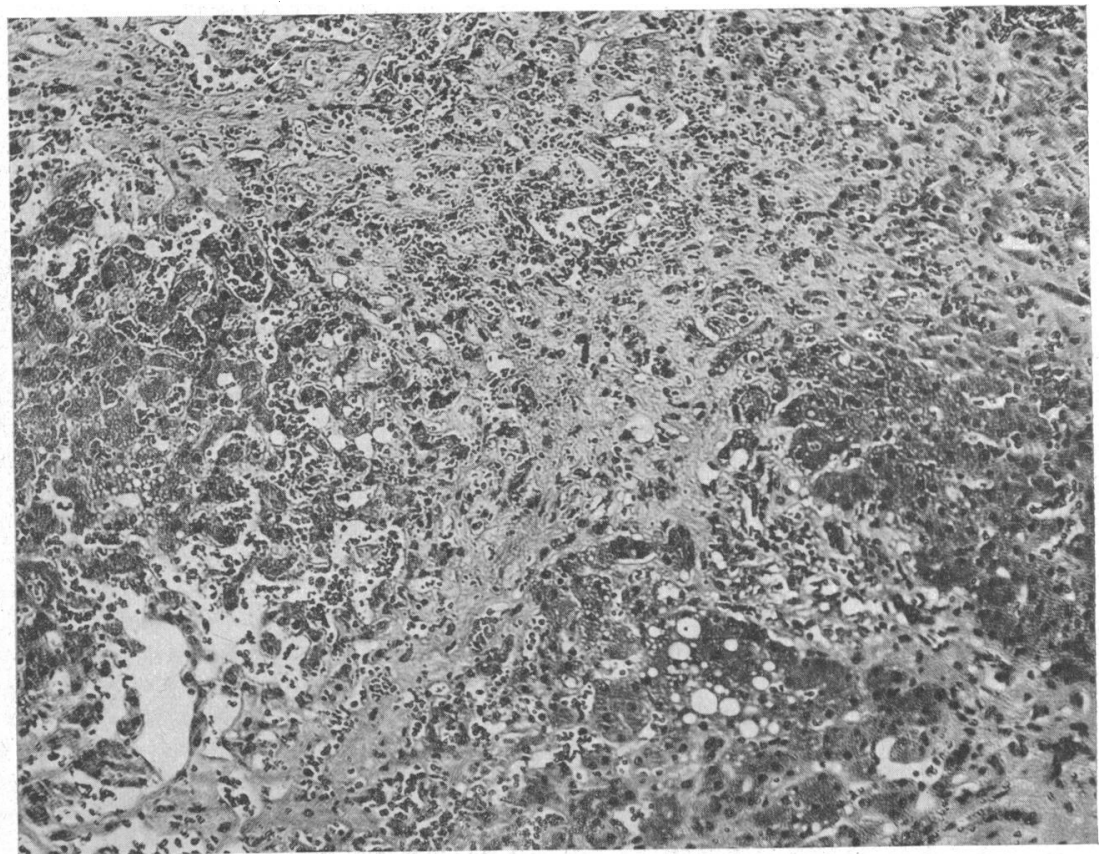


deeply jaundiced and on $14 / 8 / 44$ as yellow as a patient with carcinomatous biliary obstruction. Serum bilirubin, $22.0 \mathrm{mg} . / 100 \mathrm{ml}$. Cardiac catheterization: RAP $+29 \mathrm{~cm}$. saline; CO, 2.81 ./minute. Hepatic biopsy, II (16/9/44). Centrilobular areas linked with adjoining central areas by bands of fibrous tissue. Portal tracts normal (Fig. 11 and 12). Conspicuous bile stagnation, many bile " thrombi" being seen in canaliculi at the periphery of the lobule. 26/9/44, patient died. Final serum bilirubin, $25 \mathrm{mg} .100 \mathrm{ml}$. Post mortem: bile passages patent and full of dark bile; heart: aortic incompetence, mitral stenosis and tricuspid incompetence; no pulmonary or other infarction. Post-mortem hepatic sections: fully developed cardiac' cirrhosis. Reversed lobulation, relatively normal portal tracts apparently occupying a centrilobular position. Congestion and disappearance of liver cells adjoining the central vein (Fig. 13). Reticulin stains confirm cardiac cirrhosis.

The regression and healing of the centrilobular necrosis associated with heart failure has already been described (Case 2). If the cardiac lesion is adequately treated, a cardiac cirrhosis may similarly be associated with little functional disturbance. Acute hepatic changes and usually jaundice follow further heart failure, as illustrated by the following case history.

Case 4, E. L., a housewife, aged 38. Many previous hospital admissions with congestive heart failure due to auricular fibrillation and mitral stenosis. Responded well to usual treatment and on 15/2/45 was not in congestive failure. Serum bilirubin less than $0.5 \mathrm{mg}$.; serum albumin, $4 \cdot 2 \mathrm{~g}$.; serum globulin, $2 \cdot 2$ g. (all per $100 \mathrm{ml}$.). Bromsulphalein retention, 10 per cent. Urine, urobilinogen absent. Hepatic biopsy, a fully developed cardiac cirrhosis. Centrilobular bands of mature connective tissue joining bands from adjoining lobules. Portal tracts normal. Some dilatation of central sinusoids but no hæmorrhage. Surviving liver cells normal with normal glycogen and fatty change absent. This lesion is an inactive cardiac cirrhosis (Fig. 14). Patient remained on the verge of heart failure: on 2/2/46 re-admitted in gross congestive failure. 24/2/46: serum bilirubin, $1.6 \mathrm{mg}$.; albumin, 3.1 g.; globulin, $3.4 \mathrm{~g}$., all per $100 \mathrm{ml}$.. 31 per cent retention of bromsulphalein. Urine positive for bilirubin and urobilinogen. Patient died 25/2/46. Liver sample by aspiration thirty minutes after death: great increase in connective tissue. Fibrous bands between central areas and also joining portal tracts. A mixed picture of centrilobular "cardiac" cirrhosis and the common " portal" type (Fig. 15).

It is clear that both exacerbations and increasing duration of congestive cardiac failure result in aggravation of the hepatic lesion. Recovery from the failure leads to healing.

The Post-mortem Changes in the Liver in Patients Dying of Heart Failure

In three instances hepatic tissue was obtained less than 24 hours before death and at necropsy. The hepatic changes in the following case are typical.

Case 5, G. S., man, aged 48: cardiac failure due to chronic bronchitis and emphysema. Mildly icteric, serum bilirubin, $3.4 \mathrm{mg} . / 100 \mathrm{ml}$. Arterial blood 59 per cent saturated with oxygen; CO, 3.51 . $/$ minute and RAP, $16 \mathrm{~cm}$. saline. Hepatic biopsy 2 hours ante mortem. Severe degree of hepatic cell necrosis (grade C: Fig. 2).. Twelve hours after death (Fig. 4) the liver cells at the lobular centre had disappeared, leaving shrinkage and nuclear degeneration at the periphery. No normal cells. Cytoplasm darker, due to loss of glycogen. Surviving cells no longer closely packed together but now dissociated. Parasinusoidal spaces opened up; liver cell columns shrunken. Sinusoids contained less blood than in life.

In 14 other instances the ante- and post-mortem differences observed were of the same type as those described above. The increase in the liver changes occurring during the agonal period and immediately post mortem makes autopsy material unreliable for assessing the effects of cardiac failure on the liver in life.

\section{Relafion of Hepatic Histology to the Clinical State}

(a) Nature and duration of heart disease. Hepatic cell necrosis occurred in all forms of heart failure, the severer grades being most frequently found in mitral stenosis. In general, the longer the 
patient had been in failure the greater was the extent of underlying damage to the liver. Only 5 of the 18 patients with grade A damage had been in failure for longer than 60 days, whereas 7 of 15 patients in grade $B$ and 12 of the 17 in grade $C$ had been in failure for 60 days or more.

When cardiac cirrhosis existed, mitral stenosis was by far the most frequent accompanying heart lesion. Of the 13 patients with cardiac cirrhosis 11 had mitral stenosis and 2 pulmonary heart disease (Table I). All the patients with mitral stenosis and cardiac cirrhosis had had repeated

TABLE I

Hepatic Reticulin Changes Related to the Extent of Hepatic Cell Necrosis and to the Type of HeART FAILURe

\begin{tabular}{|c|c|c|c|c|c|c|}
\hline \multirow{2}{*}{\multicolumn{2}{|c|}{. }} & & \multicolumn{4}{|c|}{ Reticulin pattern changes (No. of patients) } \\
\hline & & & Normal & $\begin{array}{l}\text { Centrilobular } \\
\text { condensation }\end{array}$ & $\begin{array}{l}\text { Centrilobular } \\
\text { proliferation }\end{array}$ & Cirrhosis \\
\hline $\begin{array}{cc}\text { Extent of hepatic } \\
\text { A } & \cdots \\
\text { B } & \cdots \\
\text { C } & \cdots\end{array}$ & $\begin{array}{l}n e \\
\cdots \\
\cdots \\
\cdots\end{array}$ & $\begin{array}{l}\text { sis: } \\
\ldots \\
\cdots \\
\ldots\end{array}$ & $\begin{array}{r}16 \\
3 \\
4\end{array}$ & $\begin{array}{l}1 \\
2 \\
5\end{array}$ & $\begin{array}{l}1 \\
3 \\
2\end{array}$ & $\begin{array}{l}0 \\
7 \\
6\end{array}$ \\
\hline $\begin{array}{l}\text { Type of heart fai } \\
\text { Primarily valv } \\
\text { Aortic . . } \\
\text { Cor pulmonal } \\
\text { Hypertensive } \\
\text { Ischæmic }\end{array}$ & $\begin{array}{l}\text { lure } \\
\text { ular } \\
\ldots \\
\ldots \\
\ldots\end{array}$ & $\begin{array}{c}\text { tral } \\
\ldots \\
\cdots \\
\cdots \\
\cdots\end{array}$ & $\begin{array}{l}3 \\
4 \\
7 \\
6 \\
3\end{array}$ & $\begin{array}{r}2 \\
2 \\
1 \\
1 \\
2\end{array}$ & $\begin{array}{l}2 \\
0 \\
2 \\
1 \\
1\end{array}$ & $\begin{array}{r}11 \\
0 \\
2 \\
0 \\
0\end{array}$ \\
\hline
\end{tabular}

episodes of heart failure. The two patients with pulmonary heart disease and cirrhosis were in failure for the first time but the attack in both instances had lasted at least three months.

(b) Circulatory changes. There was no correlation between right auricular pressure and the extent of hepatic cell necrosis (Fig. 16). Out of 12 patients with the severest grade of hepatic cell necrosis 11 had a cardiac output less than 3.8 1./minute. A significant correlation with low output was not established, however, as many of the patients with minimal lesions had conspicuous lowering of cardiac output (Fig. 16). There was also little relation between liver necrosis and arterial oxygen saturation, but the patients with severe liver necrosis and normal or high cardiac outputs usually had very low arterial oxygen saturations (Fig. 16).

(c) The relation of cardiac cirrhosis to portal hypertension. The common Laennec cirrhosis often results in portal hypertension. The cirrhotic lesion in heart failure may resemble closely Laennec's cirrhosis and data in 28 patients were scrutinized to decide whether cardiac cirrhosis caused portal venous hypertension.

Superficial abdominal veins were not distended. Hæmatemesis did not occur. In the 28 necropsies œsophageal varicosities were not seen. Mean spleen weight for the 19 patients with cardiac cirrhosis was $175 \mathrm{~g}$. and for the 18 patients without $155 \mathrm{~g}$. The difference is not significant. Spleen histology did not differ. In the 10 patients with cardiac cirrhosis the mean volume of ascitic fluid was $1110 \mathrm{ml}$., the 18 patients without cardiac cirrhosis had a mean ascitic volume of $1260 \mathrm{ml}$. It is apparent that cardiac cirrhosis does not add portal hypertension to the clinical or post-mortem picture.

JAUNDiCE IN HeART FAILURE

Of the 50 patients, 34 had serum bilirubin levels greater than $1 \mathrm{mg} . / 100 \mathrm{ml}$. and in 16 the value exceeded $2 \mathrm{mg} . / 100 \mathrm{ml}$. Moreover, in 8 subjects jaundice was deep with a serum bilirubin greater than $4.5 \mathrm{mg} . / 100 \mathrm{ml}$. The 3 highest values were $18.0,21.5$ and $22.0 \mathrm{mg} . / 100 \mathrm{ml}$. and compare with the levels found in mechanical obstruction of the common bile duct.

Jaundice and the extent of liver damage. The serum bilirubin was usually normal in grade A and in only 5 of 18 patients was the level greater than $1 \mathrm{mg} . / 100 \mathrm{ml}$.; 12 of 15 patients in grade B 

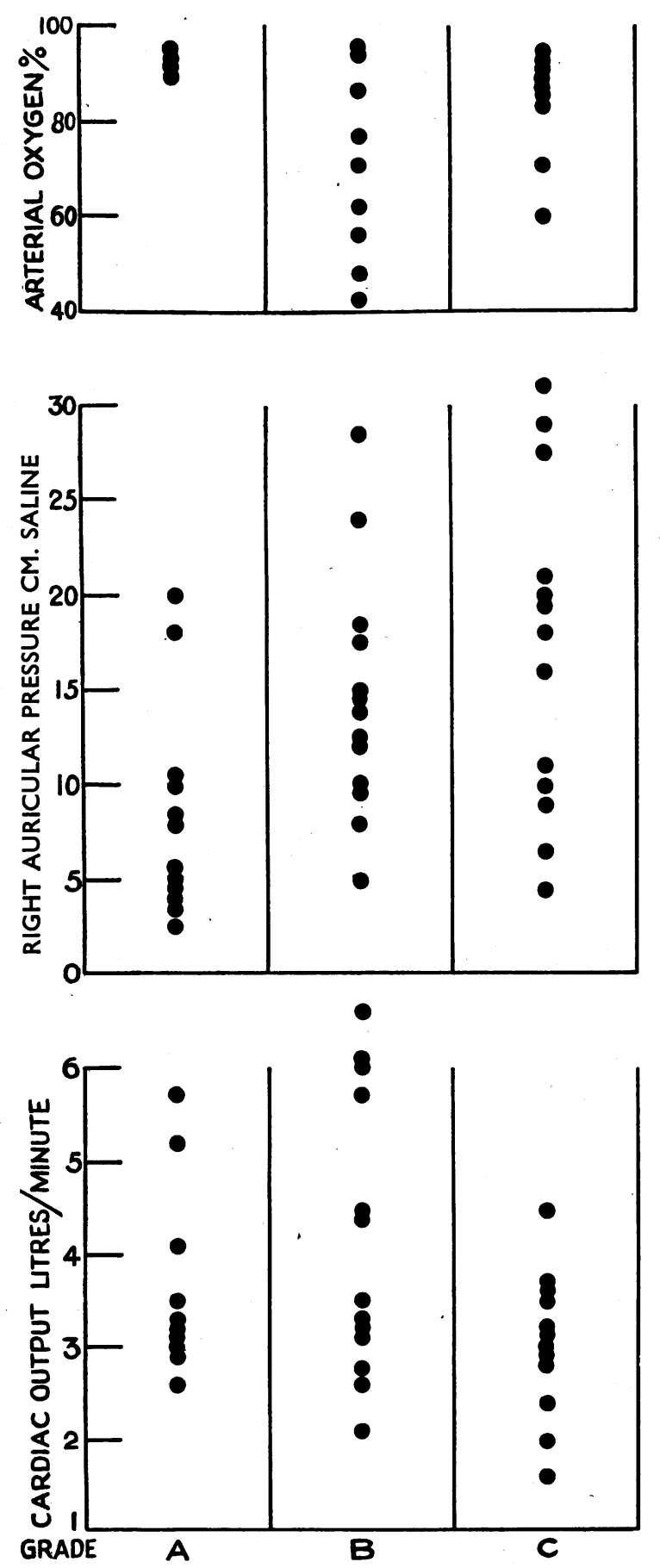

C

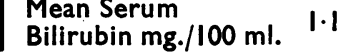

No. of Patients - 18

FIG. 17.-The relationship of extent of hepatic necrosis to the serum bilirubin concentration. to the cardiovascular changes.

FIG. 16.-The relationship of extent of hepatic necrosis 
and 15 of 17 in grade $C$ had values greater than $1 \mathrm{mg}$. There was a statistically significant difference between the mean serum bilirubin for grades A and B but none between B and C (Table II). The relation between the necrosis and the depth of jaundice is shown in Fig. 17.

TABLE II

Biochemical Results in 50 Patients with Heart failure

\begin{tabular}{|c|c|c|c|c|c|c|c|c|c|c|}
\hline \multirow[t]{2}{*}{$\begin{array}{l}\text { Extent of } \\
\text { hepatic } \\
\text { necrosis }\end{array}$} & \multicolumn{2}{|c|}{$\begin{array}{l}\text { Serum bilirubin } \\
\mathrm{mg} / 100 \mathrm{ml} \text {. }\end{array}$} & \multicolumn{2}{|c|}{$\begin{array}{l}\text { Serum alk. phos- } \\
\text { phatase } \\
\text { units } / 100 \mathrm{ml} \text {. }\end{array}$} & \multicolumn{2}{|c|}{$\begin{array}{l}\text { Serum albumin } \\
\text { g. } / 100 \mathrm{ml} .\end{array}$} & \multicolumn{2}{|c|}{$\begin{array}{l}\text { Serum globulin } \\
\text { g. } / 100 \mathrm{ml} \text {. }\end{array}$} & \multicolumn{2}{|c|}{$\begin{array}{l}\text { Bromsulph- } \\
\text { alein percent- } \\
\text { age retention at } \\
30 \text { minutes }\end{array}$} \\
\hline & $\begin{array}{l}\text { No. of } \\
\text { Cases }\end{array}$ & Mean & $\begin{array}{l}\text { No. of } \\
\text { Cases }\end{array}$ & Mean & $\begin{array}{l}\text { No. of } \\
\text { Cases }\end{array}$ & Mean & $\begin{array}{l}\text { No. of } \\
\text { Cases }\end{array}$ & Mean & $\begin{array}{l}\text { No. of } \\
\text { Cases }\end{array}$ & Mean \\
\hline Normal .. & - & $(0 \cdot 5-1)$ & - & $(4-13)$ & - & $(3 \cdot 4-5 \cdot 0)$ & - & $(1 \cdot 5-3 \cdot 0)$ & - & $(0-10)$ \\
\hline Grade A & 18 & $\begin{array}{c}1 \cdot 1 \\
0 \cdot 24 * \\
(0 \cdot 5-4 \cdot 7) \dagger\end{array}$ & 17 & $\begin{array}{c}9 \cdot 3 \\
1 \cdot 07 \\
(6 \cdot 0-25 \cdot 0)\end{array}$ & 16 & $\begin{array}{c}4 \cdot 1 \\
0 \cdot 10 \\
(3 \cdot 4-4 \cdot 7)\end{array}$ & 16 & $\begin{array}{c}2 \cdot 5 \\
0 \cdot 15 \\
(1 \cdot 4-3 \cdot 6)\end{array}$ & 6 & $\begin{array}{c}11 \cdot 3 \\
(2-30)\end{array}$ \\
\hline Grade B & 15 & $\begin{array}{c}2 \cdot 0 \\
0.33 \\
(0.5-5 \cdot 0)\end{array}$ & 15 & $\begin{array}{c}10 \cdot 3 \\
1 \cdot 21 \\
(6 \cdot 0-20 \cdot 0)\end{array}$ & 15 & $\begin{array}{c}3 \cdot 5 \\
0 \cdot 18 \\
(2 \cdot 2-4 \cdot 7)\end{array}$ & 15 & $\begin{array}{c}2.9 \\
0 \cdot 17 \\
(1 \cdot 4-4 \cdot 2)\end{array}$ & 7 & $\begin{array}{c}18 \cdot 0 \\
(1-48)\end{array}$ \\
\hline Grade C & 17 & $\begin{array}{c}3 \cdot 3 \\
0 \cdot 13 \\
(0 \cdot 9-7 \cdot 4)\end{array}$ & 13 & $\begin{array}{c}12 \cdot 3 \\
1 \cdot 03 \\
(4 \cdot 7-26 \cdot 0)\end{array}$ & 12 & $\begin{array}{c}3 \cdot 5 \\
0 \cdot 21 \\
(2 \cdot 4-5 \cdot 1)\end{array}$ & 12 & $\begin{array}{c}2.9 \\
0 \cdot 13 \\
(1 \cdot 6-3 \cdot 7)\end{array}$ & 8 & $\begin{array}{c}24 \cdot 6 \\
(7-53)\end{array}$ \\
\hline TOTAL & 50 & $\begin{array}{c}2 \cdot 1 \\
0 \cdot 19 \\
(0 \cdot 5-7 \cdot 4)\end{array}$ & 45 & $\begin{array}{c}10.5 \\
0.73 \\
(4.7-26 \cdot 0)\end{array}$ & 43 & $\begin{array}{c}3 \cdot 7 \\
0 \cdot 11 \\
(2 \cdot 2-5 \cdot 1)\end{array}$ & 43 & $\begin{array}{c}2 \cdot 8 \\
0 \cdot 12 \\
(1 \cdot 4-4 \cdot 2)\end{array}$ & 21 & $\begin{array}{c}19 \cdot 0 \\
2.53 \\
(1-53)\end{array}$ \\
\hline
\end{tabular}

$*=$ standard error of mean.

$t=$ range.

Jaundice and cardiac cirrhosis. As there were no instances of cirrhosis in grade A the comparison has been made between those with and without cirrhosis in grades B and C. The mean serum bilirubin for the 19 patients without cirrhosis was $2 \cdot 0 \pm 0 \cdot 35$ and for the 13 patients with cardiac cirrhosis $2 \cdot 9 \pm 0 \cdot 5$.

Jaundice and the cause of the heart failure. Mild degrees of jaundice may occur with all the common varieties of heart failure-valvular, hypertensive, ischæmic, or pulmonary. Deeper icterus has a closer association with valvular heart disease and in particular with mitral stenosis. Of 16 patients first observed with serum bilirubin greater than $2 \mathrm{mg} . / 100 \mathrm{ml}$, 12 suffered from mitral stenosis, one from aortic valvular disease, one from ischæmic heart failure, and two from pulmonary heart disease. Eight eventually became deeply jaundiced with a serum bilirubin value greater than $4 \mathrm{mg}$. $/ 100 \mathrm{ml}$. and of these $7 \mathrm{had}$ mitral stenosis. In 5 there was an associated tricuspid valvular incompetence.

Jaundice and the hamodynamics of heart failure. There was no correlation between the serum bilirubin values and the cardiac output. A statistical correlation $(r=0 \cdot 78)$ was established between the depth of jaundice and the venous filling pressure of the right heart, the patients having very deep jaundice also having very high right auricular pressures. There was no relationship between arterial oxygen saturation and the depth of cardiac jaundice (Fig. 18).

Jaundice and pulmonary infarction. In 42 of the 50 patients there was clear clinical or necropsy evidence of the presence or absence of pulmonary infarction. The distribution is shown in Table III. In all grades of histological severity of liver damage the mean serum bilirubin was higher where there was pulmonary infarction than where this was absent. Infarction was noted in all the varieties of heart failure except ischæmic, but was most frequently associated with mitral stenosis. Those 
patients with mitral stenosis in whom the serum bilirubin was greater than $2 \mathrm{mg} . / 100 \mathrm{ml}$. and in whom there was no pulmonary infarction usually had an accompanying incompetence of the tricuspid valve.
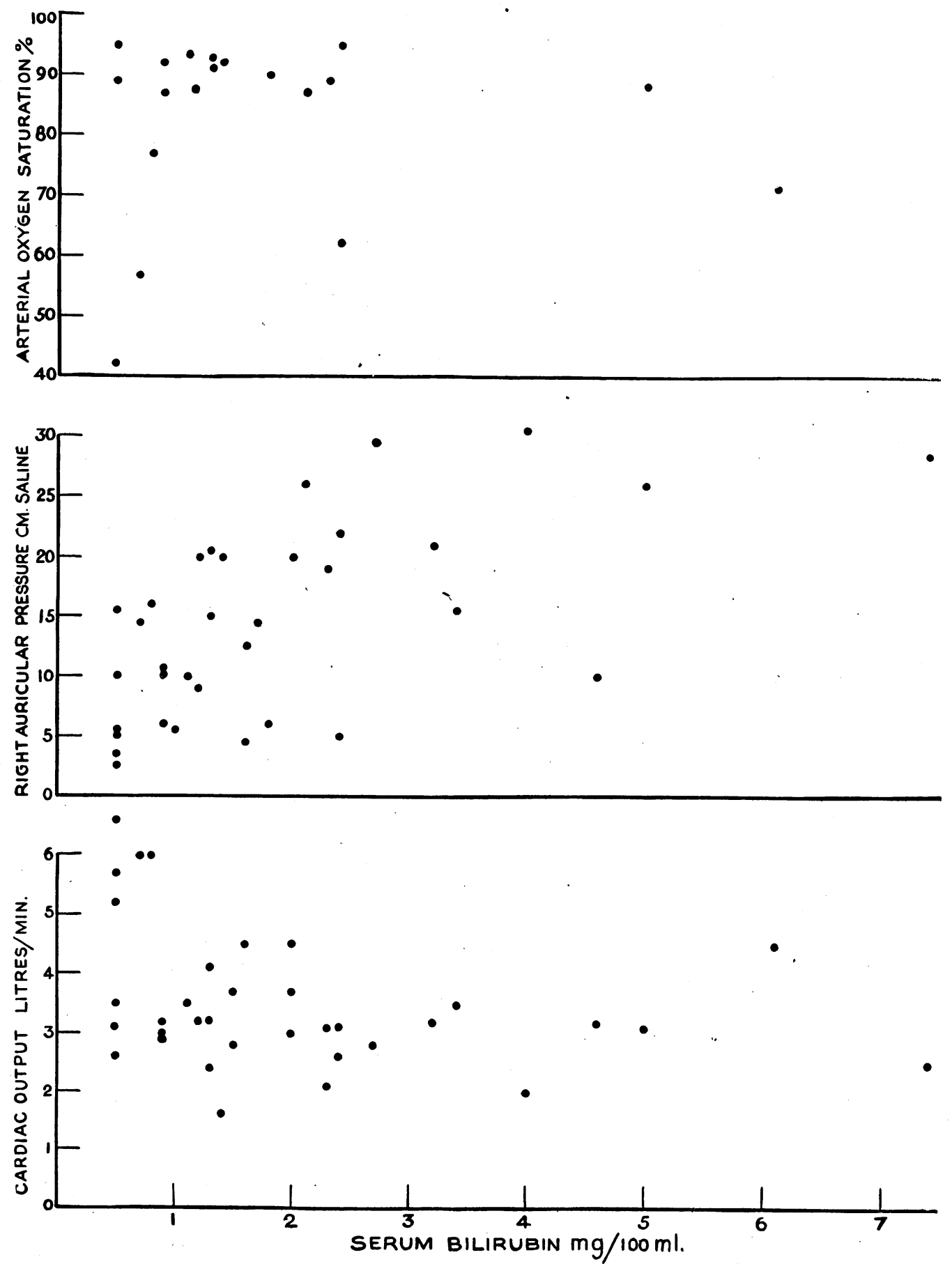

FIG. 18.-The relationship of cardiovascular changes to the serum bilirubin concentration. 
In two instances the hepatic lesion and circulatory changes were minimal although there was visible icterus. Both patients had clear evidence of pulmonary.infarction and it seems possible that this was related to the jaundice. The following case history is illustrative.

Case 6, T. E., cobbler, aged 35, with mitral stenosis. 2/1/46, sudden cough and increasing dyspnœa. Slightly jaundiced, auricular fibrillation, mild congestive heart failure. Serum bilirubin, $2.4 \mathrm{mg} . / 100 \mathrm{ml}$; serum alkaline phosphatase, albumin, globulin and colloidal gold test

TABLE III

The Relation of Serum Bilirubin Concentration and Pulmonary Infarction

\begin{tabular}{|c|c|c|c|c|c|c|c|c|c|c|c|c|}
\hline \multirow{3}{*}{$\begin{array}{l}\text { No. of } \\
\text { patients }\end{array}$} & \multirow{3}{*}{$\begin{array}{c}\text { Mean } \\
\text { serum } \\
\text { bilirubin }\end{array}$} & \multicolumn{6}{|c|}{$\begin{array}{c}\text { Histology of liver } \\
\text { Grade }\end{array}$} & \multicolumn{5}{|c|}{ Type of heart failure (No. of cases) } \\
\hline & & \multicolumn{2}{|r|}{ A } & \multicolumn{2}{|r|}{ B } & \multicolumn{2}{|r|}{$\mathrm{C}$} & \multirow[b]{2}{*}{$\begin{array}{c}\text { Mitral } \\
\text { valvular }\end{array}$} & \multirow[b]{2}{*}{$\begin{array}{l}\text { Aortic } \\
\text { valvular }\end{array}$} & \multirow[b]{2}{*}{$\begin{array}{l}\text { Cor pul- } \\
\text { monale }\end{array}$} & \multirow[b]{2}{*}{$\begin{array}{l}\text { Hyper- } \\
\text { tensive }\end{array}$} & \multirow[b]{2}{*}{$\begin{array}{l}\text { Ischæ- } \\
\text { mic }\end{array}$} \\
\hline & & No. & $\begin{array}{c}\text { Serum } \\
\text { bilirubin } \\
\text { (mean) }\end{array}$ & No. & $\begin{array}{c}\text { Serum } \\
\text { bilirubin } \\
\text { (mean) }\end{array}$ & No. & $\begin{array}{c}\text { Serum } \\
\text { bilirubin } \\
\text { (mean) }\end{array}$ & & & & & \\
\hline $\begin{array}{l}\text { Without } \\
28\end{array}$ & $\begin{array}{l}\text { pulmonary } \\
1 \cdot 4\end{array}$ & $\begin{array}{l}\text { infarc } \\
11\end{array}$ & ${ }^{\text {tion }} 0.9$ & 10 & $1 \cdot 6$ & 7 & $2 \cdot 1$ & 7 & 2 & 11 & 4 & 4 \\
\hline $\begin{array}{c}\text { With pul } \\
14\end{array}$ & monary in & $\begin{array}{c}\text { arctio } \\
3\end{array}$ & $2 \cdot 6$ & 4 & $3 \cdot 1$ & 7 & 3.5 & 9 & 2 & 1 & 2 & 0 \\
\hline
\end{tabular}

normal. Bromsulphalein test, 14 per cent retention. Urine: excess urobilinogen $(15.6 \mathrm{mg}$. in 24 hours); bilirubin. 3/1/46, cough with brown-stained sputum. Hepatic biopsy: slight centrilobular distension of sinusoids but liver histologically normal. $\mathrm{CO}, 3 \cdot 1$ 1./minute and the RAP, $+5 \mathrm{~cm}$. saline. Arterial oxygen saturation 95 per cent. Patient made an uninterrupted recovery. $7 / 1 / 46$, serum bilirubin level less than $0.5 \mathrm{mg} . / 100 \mathrm{ml}$.

Bromsulphalein. The power of the liver to excrete bromsulphalein diminished with increasing severity of liver cell necrosis (Table II). The relationship of serum bilirubin to the results of the bromsulphalein test were not nearly so close (e.g. Case 6) and in three instances the serum bilirubin level was greater than $3 \mathrm{mg} . / 100 \mathrm{ml}$. although there was less than 15 per cent retention of bromsulphalein in the 30 -minute specimen.

Urinary urobilin, urobilinogen, and bilirubin. In all but 4 ( 3 with a grade A lesion, 1 with grade C) urinary urobilinogen was present in excess. In 10 patients the 24-hourly excretion of urobilinogen was quantitatively estimated; in all but 1 there was an increase (Table IV). Although the iodine test commonly used to detect bilirubin was positive in only 10 subjects the more sensitive methylene

TABLE IV

Urinary Urobilinogen and Bilirubin in Heart Failure

\begin{tabular}{|c|c|c|c|c|c|c|c|}
\hline \multirow{3}{*}{ Grade } & \multicolumn{4}{|c|}{ Positive qualitative tests } & \multicolumn{3}{|c|}{$\begin{array}{l}\text { Quantitative urobilinogen * } \\
\mathrm{mg} . / 24 \text { hours }\end{array}$} \\
\hline & \multirow{2}{*}{$\begin{array}{l}\text { No. of } \\
\text { patients }\end{array}$} & \multirow{2}{*}{ Urobilinogen } & \multicolumn{2}{|c|}{ Bilirubin } & \multirow{2}{*}{$\begin{array}{l}\text { No. of } \\
\text { patients }\end{array}$} & \multirow[b]{2}{*}{ Mean } & \multirow[b]{2}{*}{ Range } \\
\hline & & & Iodine & $\begin{array}{c}\text { Methylene } \\
\text { blue and diazo }\end{array}$ & & & \\
\hline Normal & - & 0 & 0 & 0 & 一 & - & $0-4$ \\
\hline $\begin{array}{l}\text { A } \\
\text { B } \\
\mathbf{C}\end{array}$ & $\begin{array}{l}18 \\
15 \\
17\end{array}$ & $\begin{array}{l}15 \\
15 \\
16\end{array}$ & $\begin{array}{l}1 \\
3 \\
6\end{array}$ & $\begin{array}{r}3 \\
10 \\
11\end{array}$ & $\begin{array}{l}2 \\
4 \\
4\end{array}$ & $\begin{array}{r}8 \cdot 9 \\
12 \cdot 5 \\
14 \cdot 2\end{array}$ & $\begin{array}{l}2 \cdot 2-16 \\
4 \cdot 5-40 \\
4 \cdot 3-45\end{array}$ \\
\hline
\end{tabular}

* Normal excretion is $0-4 \mathrm{mg} . / 24$ hours. 
blue and diazo tests were positive in 24 patients. Positive results were most frequent in the patients with the more severe liver damage and with the higher serum bilirubin values.

\section{OTHER BIOChEMical DATA}

Serum alkaline phosphatase was usually normal (Table II). In 5 of 50 subjects the value was greater than the 13 units taken as the upper limit of normal. However, the concentration was always less than the 30 units used to differentiate primary parenchymatous from obstructive jaundice (Sherlock, 1946). Some of the patients with the deepest jaundice had the lowest values for alkaline phosphatase; nor was the serum phosphatase level related to cirrhosis.

Although the mean values for total serum protein, for serum albumin and for serum globulin were within normal limits (Table II) there was a great deal of variation in the individual patient. Twelve of 43 patients had a serum albumin value less than the normal lower limit of $3.4 \mathrm{~g} . / 100 \mathrm{ml}$. and 18 patients had serum globulin levels above the upper normal limit of $3 \mathrm{~g} . / 100 \mathrm{ml}$. The serum proteins were occasionally greatly disturbed; in 4 patients serum albumin was less than $2.5 \mathrm{~g} . / 100 \mathrm{ml}$. and in 4 other patients also the serum globulin level was greater than $3.5 \mathrm{~g} . / 100 \mathrm{ml}$.

Low serum albumin values occurred only in grades B and C. There was a significant difference between the values of grade A compared with the severer grades B and C. Although 4 of the 16 patients in grade $\mathrm{A}$ had conspicuous globulin increases the changes were common in grades B and C, 8 of the 15 patients in grade $B$ and 6 of the 12 in grade $C$ showing an increase. There was no significant difference between the serum protein values of those with and those without cardiac cirrhosis. Little relation was found between the duration of the congestive failure and the serum protein values.

Diminution of serum albumin was most frequently encountered in patients suffering from mitral stenosis or cor pulmonale. Six of 17 patients with mitral stenosis and 5 of 9 patients with pulmonary heart failure had changing values lower than $3.4 \mathrm{~g} . / 100 \mathrm{ml}$. Serum protein, and particularly albumin, passes to a certain extent into œdema fluid. The patients with the worst œedema would be expected to have the lowest serum albumin and highest serum globulin values. This proved to be the case and might partially explain the association of depressed serum albumin and raised serum globulin with mitral stenosis and cor pulmonale in which odema tends to be greatest.

A positive colloidal gold test was obtained in only 4 of 36 patients, 2 of the positive results occurring in grade B and 2 in grade C. Two of the patients had cardiac cirrhosis; the remaining 11 patients with cardiac cirrhosis showed a negative colloidal gold test.

\section{Discussion}

\section{Post-mortem Changes in the Liver in Heart Failure}

The rapid autolytic changes in the diseased liver after death have been referred to above, and the present observations confirm those of Popper (1948), and show that post-mortem hepatic autolysis is particularly rapid in heart failure. There is a discrepancy between the incidence of fatty change in our series and that usually described in textbook accounts of heart failure based on selected necropsy material, which taken from the liver in heart failure is almost useless for correlation with in vivo changes.

\section{Centrilobular Hepatic Necrosis in Heart Failure}

The liver is particularly sensitive to oxygen lack and the integrity of the liver cell depends on an adequate oxygen supply. The liver cells at the centre of the lobule receive blood at a lower oxygen tension than at the periphery (Blalock and Mason, 1936) and are therefore more susceptible to any fall in the oxygen supply to the liver. Anoxia is known to cause both degeneration of central liver cells (Martin, Bunting, and Loevenhart, 1916), and dilatation of sinusoids (Seneviratne, 1949). 
In man, as the cardiac output diminishes, the hepatic blood flow diminishes in proportion (Myers and Hickam, 1948). ${ }^{-}$The oxygen supply to the liver decreases with diminishing cardiac output. Centrilobular hepatic necrosis in heart failure ought therefore to bear some relation to the degree of depression in cardiac output, but there is a group with high cardiac output showing conspicuous centrilobular necrosis in whom other factors such as low arterial oxygen saturation and anæmia may be involved.

The oxygen supply to the liver depends not only on the hepatic blood flow but also on the oxygen content of the portal venous and hepatic arterial blood. A correlation between arterial oxygen unsaturation and the extent of centrilobular necrosis might be anticipated. Very few estimations were available but a positive correlation was not established. However, six patients with pulmonary heart disease with high cardiac output did have low arterial oxygen saturations. Five of these had grade B liver cell necrosis and in these subjects the reduced arterial oxygen saturation seemed an important factor in the production of the liver lesion.

Increased pressure in the hepatic veins might conduce to the centrilobular necrosis. Although patients with the maximal hepatic necrosis often have high right auricular and presumably hepatic venous pressures, the correlation was not constant. The patient with constrictive pericarditis who probably had the highest hepatic venous pressure also showed very severe centrilobular necrosis, a condition found in most patients with constrictive pericarditis. As Bolton (1914) pointed out it is doubtful whether the centrilobular changes produced by "passive" venous congestion are mechanical since the rise of pressure must extend right through the lobule to the portal veins. $\mathrm{He}$ believed them to be due to "a nutritional disturbance and presumably oxygen lack resulting from blood flow changes." Another factor determining the extent of the necrosis is the duration of the heart failure, as shown in the present series.

\section{Cardiac Cirrhosis}

Heart failure can undoubtedly produce a centrilobular cirrhosis. The relative rarity of this condition is probably related to the infrequency of prolonged heart failure. Most patients die in the stage of centrilobular reticulin condensation and never pass to the proliferative regenerative phase. Repeated episodes of failure are necessary for the development of full cardiac cirrhosis. Patients with rheumatic mitral stenosis, responding intermittently to treatment, are therefore particularly prone to develop cardiac cirrhosis. If patients with other forms of heart failure survive for a sufficient length of time they too can develop the same lesion. - This is illustrated by the two patients with chronic cor pulmonale who survived three months and showed cardiac cirrhosis.

Although the connective tissue in heart failure is primarily centrilobular, in the later stages the portal tracts become involved. Fibrous bands link not only central areas but also portal tracts (Fig. 15). This may account for the reported frequency of portal cirrhosis in heart failure (Katzin, Waller and Blumgart, 1939). Serial hepatic biopsies show that the essential cirrhosis of heart - failure is a centrilobular one and involvement of the portal tracts is merely a later confusing feature.

The patients with cardiac cirrhosis were not more deeply jaundiced than those without; neither was there any difference in the serum protein values or the colloidal gold test. Cardiac cirrhosis did not seem to be causing intrahepatic vascular obstruction. Moreover, if the heart failure is controlled the acute hepatic changes disappear and the liver shows only avascular fibrous bands passing between central veins. Blood biochemistry returns to normal, as in Case 2. The hepatic lesion is quiescent or latent. This is analogous to the latent cirrhosis sometimes resulting from acute "viral " hepatitis (Sherlock, 1948). It is uncertain whether latent cardiac cirrhosis can eventually lead to portal venous hypertension. This consideration is important in constrictive pericarditis with associated centrilobular cirrhosis. Surgery may relieve the cardiac embarrassment and the cirrhosis will become latent. Other things being equal, cardiac cirrhosis should not contraindicate operation on patients with constrictive pericarditis. 


\section{Jaundice in Heart Failure}

Although frank jaundice is rare, the serum bilirubin in heart failure is usually increased (Jolliffe, 1930; Kugel and Lichtman, 1933; Routier et al., 1935; Chávez et al., 1943). The present findings also demonstrate this. There are various causes of cardiac jaundice.

(A) Hepatogenous jaundice. This implies that in heart failure the liver cells are inadequate to excrete the bile pigment. The impaired bromsulphalein test is in keeping with this, and, in general, the greater the extent of liver cell necrosis the deeper the icterus (Fig. 17). There are many exceptions, and histological liver cell damage cannot entirely explain cardiac jaundice.

(B) Obstructive jaundice. Eppinger (1937) believed that cardiac jaundice was due to obstruction of bile capillaries both by pressure on the outside by distended veins and by inspissated bile thrombi within. The obstruction theory may be related to the height of the venous pressure within the hepatic lobule. The normal biliary secretory pressure is $20-30 \mathrm{~cm}$. water (McMaster, Broun and Rous, 1923). Many patients with heart failure have right auricular pressures of $20 \mathrm{~cm}$. saline. The hepatic vein pressure may be assumed to be higher than this and may be greater than the pressure at which bile can be secreted. A mechanical obstruction to the intralobular bile canaliculi might thus exist. Moreover, patients with deep jaundice often have very high right auricular pressures (Case 3). The close association of tricuspid valvular incompetence (with presumably high hepatic venous pressures) and deep jaundice has already been noted.

Coagulation of bile in the minute canaliculi to form " bile thrombi" is commonly regarded as evidence of biliary obstruction. Bile thrombi are conspicuous in the livers of patients with deep cardiac jaundice, and are seen whenever jaundice is deep and particularly when the bile is viscid, as in hæmolytic crises. In addition, the centrilobular destruction of liver cells and hæmorrhage in heart failure may themselves disorganize the bile canaliculi and produce stagnation of bile and hence thrombi.

Other evidence against the hepatic venous pressure-obstructive theory of cardiac jaundice may be given. The relationship between high venous pressure and jaundice is not constant (Fig. 18) and some patients with very high right auricular pressures are not jaundiced. At necropsy the gall bladder and bile passages, even with the deepest jaundice, are full of dark bile. The fæces are perhaps darker than normal and do not suggest biliary obstruction. Further, the biochemical data are unlike those of biliary obstruction. Serum alkaline phosphatase is normal as are the blood cholates (Sherlock and Walshe, 1946). Urobilinogen is present in excess in the urine. Intrahepatic biliary obstruction related to high venous pressure is therefore unlikely to be an important cause of cardiac jaundice.

(C) Hæmolytic jaundice. The icterus of heart failure is often related to hæmorrhages into the tissues, particularly pulmonary infarction. The hæmoglobin in the tissues becomes changed to bilirubin. The excess of pigment cannot be excreted by a liver damaged by heart failure, and jaundice results (Kugel and Lichtman, 1933).

There are many points in favour of this hypothesis. There is an excess of iron pigment in some tissues in heart failure. Even without frank infarction the pulmonary alveoli usually contain " heart failure" cells. These macrophages show iron pigment presumably derived from red blood corpuscles. Bilirubin must also have been formed constituting an additional excretory load on the liver. In one patient with pulmonary infarction the serum bilirubin was on the whole higher than those without, but there were many exceptions. In some patients jaundice developed after infarction although the right auricular pressure and cardiac output were not greatly changed and liver biopsy showed only minimal histological changes (Case 6). In these patients jaundice could only be associated with infarction. All the patients with minimal liver cell damage who were jaundiced had clear evidence of pulmonary infarction. The occasional observation of increased serum bilirubin values with relatively normal results for the bromsulphalein retention tests also suggested a hæmolytic jaundice. The very dark bile contained in the full bladder and bile ducts, the excess of urobilin in the urine, and the other biochemical findings in the blood were compatible with hæmolytic icterus. 
At the same time pigment overload cannot be the only cause of cardiac jaundice. Rich and Resnik (1926) introduced into the tissues of patients with heart failure a volume of blood equal to that found in pulmonary infarctions and failed to increase the serum bilirubin. Although bilirubinuria is not found in hæmolytic icterus, it was frequent in our patients with cardiac jaundice. Finally, jaundice occurred without pulmonary infarction. It was especially conspicuous in association with tricuspid incompetence in which pulmonary vascular congestion is minimal (Case 3).

\section{Diagnosis of Cardiac .Cirrhosis}

That clinical recognition of cardiac cirrhosis is usually impossible is suggested by the present finding, and by the work of Boland and Willius (1938). It should be suspected in mitral disease with repeated episodes of heart failure especially if there is an associated tricuspid valvular incompetence. Most patients with heart failure and deep jaundice also have a cardiac cirrhosis, but most patients in whom cirrhosis is present will give no clinical indications -of this lesion.

\section{SUMMARY}

Sections of liver were obtained by aspiration biopsy or occasionally by necropsy from 50 patients in congestive heart failure and from one patient with constrictive pericarditis. A full post-mortem examination was carried out in 28 subjects. Changes occurring in the agonal and immediate postmortem periods were such that necropsy sections proved unreliable for assessing the effects of cardiac failure on the liver.

Centrilobular hepatic necrosis was almost invariable. If the heart failure worsened the necrosis spread peripherally whereas if the cardiac condition responded to treatment the liver lesion healed.

Connective tissue changes originated at the centre of the liver lobules. Reticulin condensation occurred first; this was followed by reticulin proliferation and eventually spread of connective tissue from central vein to adjoining central veins giving a cardiac cirrhosis. Cardiac cirrhosis became latent if the heart disease was amenable to treatment.

Structural changes in the liver were perhaps related to circulatory changes, namely, reduction in cardiac output, diminution of the arterial oxygen saturation, height of the hepatic venous pressure, and also to the duration of heart failure.

A raised serum bilirubin was very common; frank jaundice was rare and usually confined to patients with mitral stenosis and tricuspid valvular incompetence. The mean serum bilirubin value was higher in the patients with the severer grades of hepatic cell necrosis and when there was evidence of associated pulmonary infarction. There was no constant association between serum bilirubin values and cardiac output or arterial oxygen unsaturation. However, patients with deep jaundice tended to have very high right auricular pressures.

The power to excrete bromsulphalein diminished with increasing severity of liver cell necrosis. Urine urobilinogen was increased. Bilirubin was often detected in the urine. Serum alkaline phosphatase and total and differential protein values were usually normal. The serum colloidal gold test was usually negative.

It was concluded that cardiac cirrhosis has no specific clinical, blood biochemical, or circulatory associations, and that it does not cause intrahepatic portal venous obstruction.

The complexity of cardiac jaundice has been discussed. Support can be found for hepatocellular, obstructive, and hæmolytic theories. In most patients multiple factors are present and the exact cause of the jaundice cannot be determined.

The histological preparations were made by Mr. J. C. Griffin and the technical staff of the Pathology Department - of the Postgraduate Medical School of London. Mr. E. V. Willmott took the microphotographs. I should like 
particularly to thank Miss Veryan Walshe, M.Sc., for biochemical assistance, and also Dr. Sheila Howarth, Professor J. McMichael and Professor E. P. Sharpey-Schafer for allowing me access to their records from which the circulatory data quoted in this paper were derived. Professor J. H. Dible gave much advice on the interpretation of hepatic histology. The patient with constrictive pericarditis was studied by kind permission of Dr. William Evans.

Part of the work was performed during the tenure of a Beit Memorial Research Fellowship.

\section{REFERENCES}

Bernstein, M., LeWinn, E. B., and Simkins, S. (1942). J. Lab. and clin. Med., 28, 1.

Blalock, A., and Mason, H. F. (1936). Amer. J. Physiol., 117, 328.

Boland, E. W., and Willius, F. A. (1938). Arch. intern. Med., 62, 723.

Bolton, C. (1914). J. Path. Bact., 19, 258.

Chávez, I., Sepúlveda, B., and Ortega, A. (1943). Amer. J. med. Ass., 121, 1276.

Eppinger, H. (1937). Die Leberkrankheiten, J. Springer, Vienna.

Gellis, S. S., and Stokes, J., Jr. (1945). J. Amer. med. Ass., 128, 782.

Haslewood, G. A. D., and King, E. J. (1937). Biochem. J., 31, 920.

Helm, J. D., and Machella, T. E. (1942). Amer. J. digest. Dis., 9, 141.

Iversen, P., and Roholm, K. (1939). Acta med. scand., 102, 1.

Jolliffe, N. (1930). J. clin. Invest., 8, 419.

Katzin, H. M., Waller, J. V., and Blumgart, H. L. (1939). Arch. intern. Med., 64, 457.

Kiernan, F. (1833). The Anatomy and Physiology of the Liver, J. H. Green, Philosophical Transactions, Royal Soc. of London.

King, E. J., and Armstrong, A. R. (1934). Canad. med. Ass. J., 31, 376.

- Haslewood, G. A. D., and Delory, G. E. (1937). Lancet, 1, 886.

,,-- and Beall, D. (1942). Ibid., 1, 207.

Kugel, M. A., and Lichtman, S. S. (1933). Arch. intern. Med., 52, 16.

Maclagan, N. F. (1944). Brit. J. exp. Path., 25, 15.

McMaster, P. D., Broun, G. O., and Rous, P. (1923). J. exp. Med., 37, 685.

McMichael, J., and Sharpey-Schafer, E. P. (1944). Brit. Heart J., 6, 33.

Martin, G. H., Bunting, C. H., and Loevenhart, A. S. (1916). J. Pharmacol., 8, 112.

Myers, J. D., and Hickam, J.'B. (1948). 'J. clin. Invest., 27, 620.

Pollock, M. R. (1945). Lancet, 2, 626.

Popper, H. (1948). Arch. Path., 46, 132.

Rich, A. R., and Resnik, W. H. (1926). Bull. Johns Hopk. Hosp., 47, 75.

Routier, D., Cottet, J., and Molinghen, P. (1935). Arch. Mal. Appar. dig., 25, 801.

Seneviratne, R. D. (1949). Quart. J. exp. Physiol., 35, 77.

Sherlock, S. (1945). Lancet, 2, 397.

- (1946). J. Path. Bact., 58, 523.

- (1948). Lancet, 1, 817.

- , and Walshe, V. (1946). Unpublished observations.

Watson, C. J. (1937). Arch. intern. med., 59, 196. 